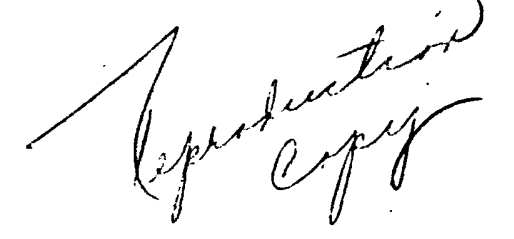

UNITED STATES DEPARTMENT OF THE INTERIOR

GEOLOGICAL SURVEY

Stability of Highwalls in Surface Coal

Mines, Western Powder River Basin, Wyoming and Montana

By

Fitzhugh T. Lee, William K. Smith, and William Z. Savage

Open-File Report 76-846

1976

This report is preliminary and has not been edited or reviewed for conformity with U.S. Geological Survey standards or nomenclature. 
Abstract-1

Introduction-1.- 2

Acknowledgments-1. 2

Summary of geology of study area-1 4

Hydrology-1.2 6

Geotechnical investigations-1 7

Methods of investigation-1... 7

Attitudes and spacing of joints-a 9

Laboratory investigations-10.-_- 10

General observations on the stability of highwalls in the study area-1

Possible effects of desiccation on stability-a.- 25

Possible effects of overconsolidation on stability-..-...-.-. 25

Other factors affecting stability-a.-. 30

Summary of observations-1 31

Stability analyses and predictions-1.- 31

Method of analysis-a 31

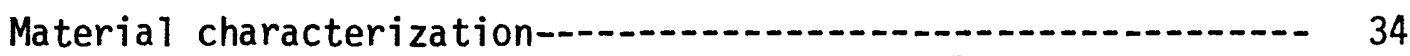

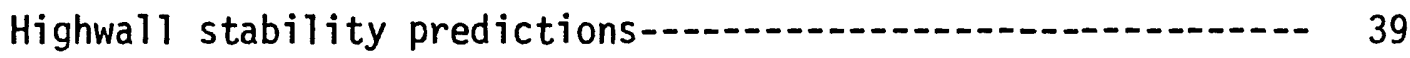

Concluding remarks and future plans-_..- 45

References cited-1.-1 50. 


\section{Illustrations}

Page

Figure 1. Index map showing location of the Powder River Basin and

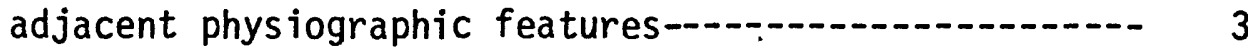

2. Map of study area-a 5

3. Plan of the Decker mine as of June 1975 showing mapping

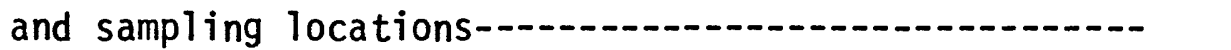

4. Typical plot from triaxial test-_.-. 13

5. Variation of peak and residual strengths with confining , pressure for selected samples, Decker mine, Montana---

6. Variation of Young's modulus with confining pressure for selected samples, Decker mine, Montana--...-...-.-.- 15

7. Least squares fit of $\frac{\sigma_{1-\sigma_{3}}}{2}$ vs. $\frac{\sigma_{1+\sigma_{3}}}{2}$ for shale of sample series 1 (table 1)

8. Least squares fit of $\frac{\sigma_{1-} \sigma_{3}}{2}$ vs. $\frac{\sigma_{1+\sigma_{3}}}{2}$ for shale of sample series $3 A$ (table 1 )

9. Least squares fit of $\frac{\sigma_{1-} \sigma_{3}}{2}$ vs. $\frac{\sigma_{1+\sigma_{3}}}{2}$ for siltstone of

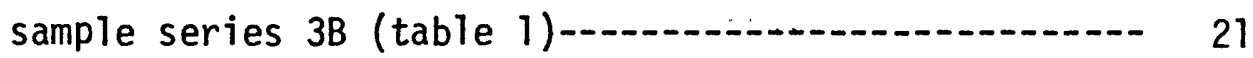

10. Least squares fit of $\frac{\sigma_{1-} \sigma_{3}}{2}$ vs. $\frac{\sigma_{1+\sigma_{3}}}{2}$ for sandstone of sample series 3D (table 1)--.-.-.-.- 22

11. Least squares fit of $\frac{\sigma_{1-\sigma_{3}}}{2}$ vs. $\frac{\sigma_{1+\sigma_{3}}}{2}$ for coal of sample series 4 (table 1)

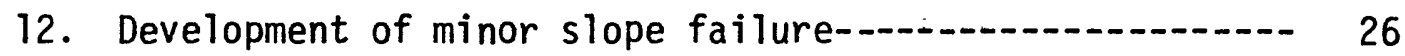

13. Hypothetical sequence of loading and deformational

history in the western Powder River Basin-.......... 28

14. Coulomb-Mohr envelope $(\tau=c+\sigma \tan \phi)$ and Mohr circles-- 33 
Figure 15. Idealized cross section through an open-pit mine in the Fort Union Formation

16. Generalized stratigraphic column through the Decker mine showing relative amounts of the various overburden rock types-1

17. Potential surfaces of failure for which safety factors were calculated-1

18. Perspective sketch showing part of proposed instrumentation plan for slope-deformation monitoring, Decker mine, Montana

19. Idealized cross section showing proposed instrumentation plan for slope-deformation monitoring, Decker mine, Montana

Tables

Table 1. Physical-property test results for samples from Decker mine, Montana

2. Unconfined physical-property test results for samples from Decker mine, Montana, and Big Horn mine, Wyoming

3. Range of values of $\phi$ and c calculated at the 99-percent confidence level

4. Average properties of typical Fort Union rocks at the Decker mine, Montana 
Page

Table 5. Safety factors calculated by the finite-element method for the five potential failure surfaces in figure 17--- 44 


\title{
STABILITY OF HIGHWALLS IN SURFACE COAL MINES, WESTERN POWDER RIVER BASIN, WYOMING AND MONTANA
}

\author{
By FITZHUGH T. LEE, WILLIAM K. SMITH, \\ and WILLIAM Z. SAVAGE
}

\begin{abstract}
Preliminary results from the first part of a two-part investigation of the stability of highwalls in open-pit coal mines in the Fort Union Formation of the western Powder River Basin of Wyoming and Montana indicate that these highwalls are subject to time-dependent deformation. Field investigations and laboratory physical-properties tests of coal and overburden rocks suggest that several factors influence highwall stability. Some of these factors are rebound of overconsolidated rocks, desiccation, water, orientation and spacing of fractures, and strength and deformation properties. Factors of safety for a typical highwall in the study area (calculated by the finite-element method) may be less than 1.0 when open fractures are present and the highwall has degraded. Although it is concluded that most open-pit mines in the Fort Union Formation within the study area have generally stable highwalls, these highwalls do deteriorate and become progressively less stable. Because of this, postmining failures are common and could be critical if mining were delayed and then resumed after a period of several months.

The second part of the investigation will utilize field measurements of rock-mass properties and instrumentation of actively mined highwalls to obtain data for comparison with the results of the initial investigation.
\end{abstract}


Because the height of highwalls will increase as the more shallow coal is exhausted, these data will also be used to predict the behavior of slopes higher than those presently found in the western Powder River Basin.

\section{INTRODUCTION}

The problem of safe pit-slope design must be considered in any analysis of potential coal development in a given region. The purpose of this report is to present the results of the first part of a two-part investigation of the stability of highwalls in open-pit coal mines in the western Powder River Basin near Sheridan, Wyo. (fig. 1). The study is a part of the geotechnical investigations being made for the Environmental Studies of Energy Lands Program of the U.S. Geological Survey. This report includes the results of field mapping and physical-properties testing of coal and overburden rocks, discussion of factors that control highwall stability, and predictions of slope behavior. The second part of the investigation will be a field study to determine actual highwall deformation through instrumentation and in situ testing. The results of this work will be compared with the predicted slope behavior to determine the accuracy and applicability of our initial findings and to make necessary corrections.

\section{Acknowledgments}

The cooperation of personnel of the Decker Coal Company, the Big Horn Coal Company, and the Welch mine in permitting access to their properties is gratefully acknowledged. Assistance with field mapping, sampling, laboratory testing, computer analyses, and drafting was given by A. D. Barnosky and G. L. Twombly of the U.S. Geological Survey. Most of the physical-properties testing was carried out at the University of Colorado by M. P. Fahy and M. E. Shaffer and was supervised by H. Y. Ko. The work of others who contributed to the study is acknowledged at appropriate places in the text. 
Figure 1.--Index map showing location of the Powder River Basin and adjacent physiographic features. Study area is indicated by shaded pattern.

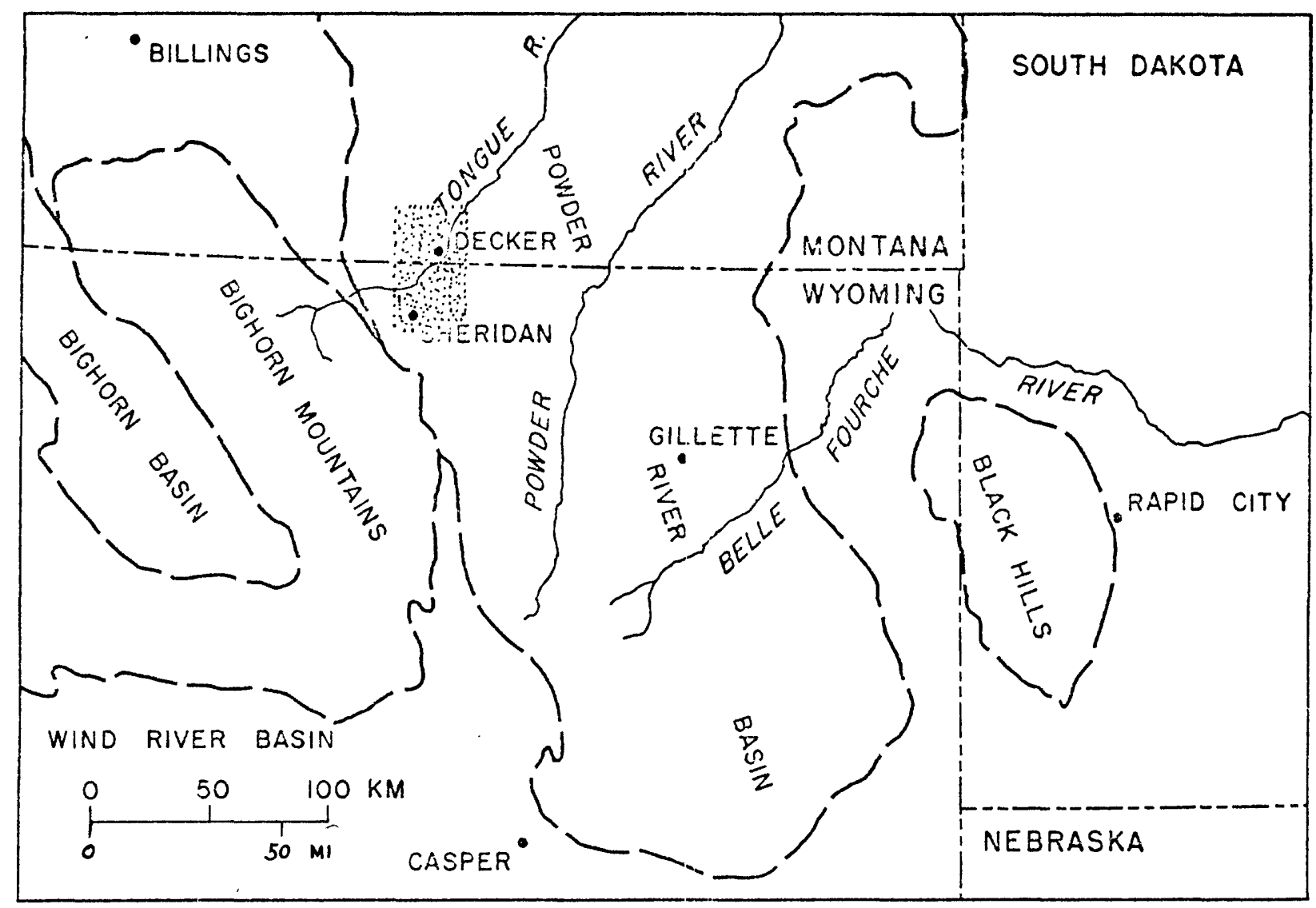




\section{SUMMARY OF GEOLOGY OF STUDY AREA}

The study area (outlined by the shaded pattern in fig. 1) is located in the western part of the Powder River Basin near Sheridan, Wyo.

In the study area, coal beds occur in the lower Tertiary sedimentary rocks of the Fort Union and Wasatch Formations (Law and Grazis, 1972; Keefer, 1974). Current coal mining in the area is within the Tongue River Member of the Fort Union Formation. Rocks in this member are generally soft, lightgray to light-brown interbedded shales, claystones, siltstones, and sandstones, and black to dark-brown coal. Except for some siltstones and massive but discontinuous sandstones, beds in the overburden rocks are lenticular and intertongued, and are generally weakly cemented. Alternating beds of soft claystone, siltstone, and sandstone grade into each other, both vertically and horizontally, making correlation difficult even over distances of a few meters. The coal has many fractures and disintegrates (slakes) rapidly upon drying.

Beds within the Fort Union and Wasatch Formations generally strike northward, with a gentle easterly dip $\left(0^{\circ}-2^{\circ}\right)$ throughout the study area. Some local folds were observed at the mines and outcrops.

In the study area, northeast-and northwest-trending lineations are alined with local rivers and streams, among which the Tongue River is the largest. These lineations are thought by some to be fault controlled (Matson and Blumer, 1973, p. 21). Just south of the Decker mine (fig. 2) there is a steeply dipping fault trending $\mathrm{N} .50^{\circ} \mathrm{E}$. and having about $61 \mathrm{~m}$ of vertical displacement, the southeast block being downthrown (Van Voast, 1974, p. 9). Other faults having this general attitude are located northwest and southeast of the Decker mine (Keefer, 1974; Law and Grazis, 1972). The Decker area is on the northeast flank of the northwest-trending Ash 
Figure 2.--Map of study area. Equal-area, lower-hemisphere diagrams show joint orientations measured in Fort Union and Wasatch rocks in different parts of the study area. Location of diagrams approximately corresponds to source of data. Contours are in percent per 1-percent area. A, joints in outcrops and in Welch and Big Horn mines, contours 2, 4, 6, and 8 percent. B, joints in outcrops, contours $1,4,8$, and 12 percent. C, joints in outcrops around perimeter of Decker mine, contours 1,4,8, and 12 percent. $D$, joints in outcrops, contours $1,2,4,6,10$, and 15 percent. E, joints in Decker mine, contours $1,3,6,9$, and 12 percent. 


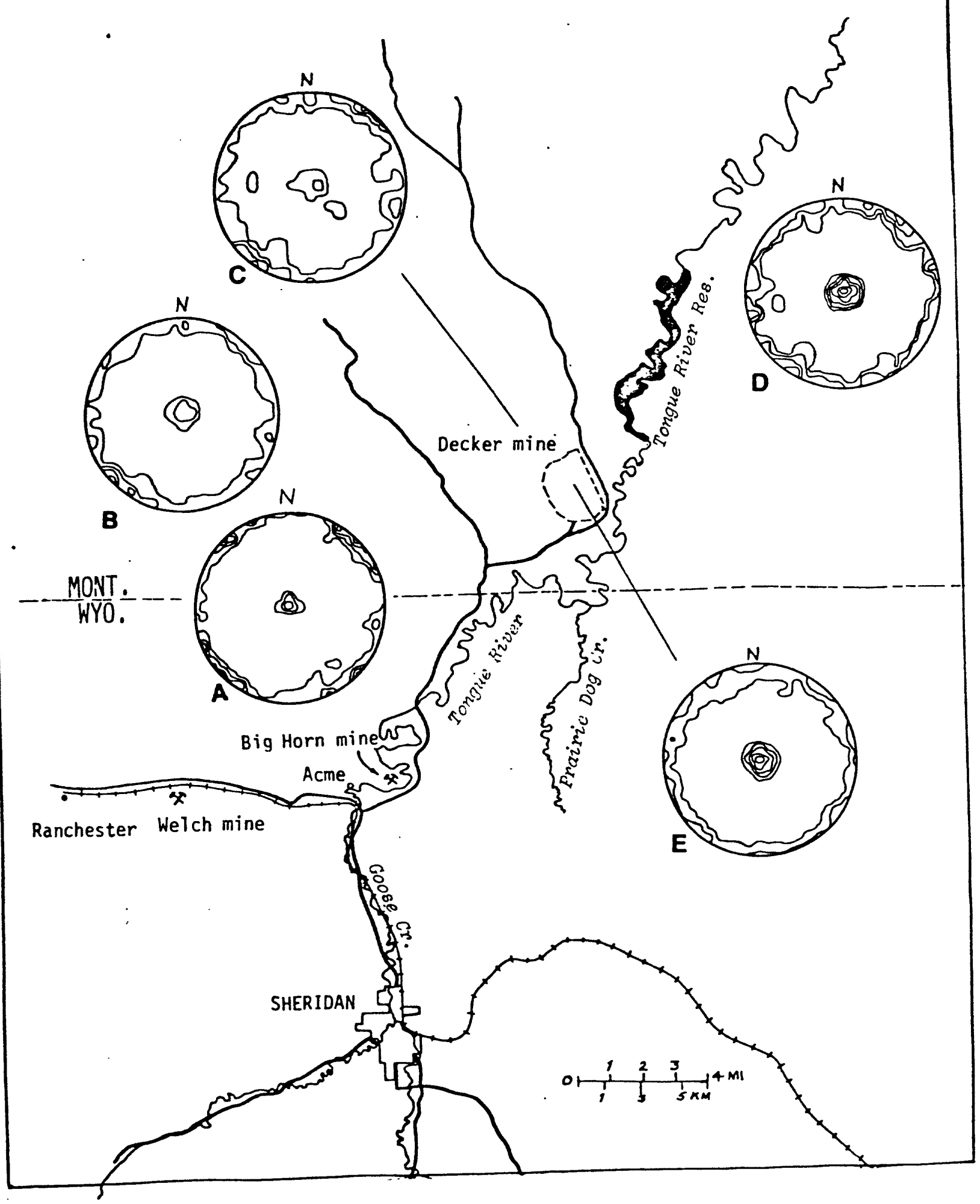


Creek anticline, which contains a producing oil field (Matson and Blumer, 1973, p. 21).

\section{HYDROLOGY}

The fact that the coal beds are the principal aquifers in the study area makes an understanding of the effect of mining on the ground-water regime especially important. The most extensive ground-water studies in the study area have been made at the Decker mine, beginning in 1970, by the Montana Bureau of Mines and Geology (Van Voast, 1974). This group has monitored water-level decline in several wells, conducted pumping tests, and estimated flow rates into the mine.

Two coal beds are important to the hydrology of the Decker mine area: the Anderson-Dietz No. 1 (the seam being mined), and the underlying Dietz No. 2 (Matson and Blumer, 1973, p. 26). These two beds are separated by about $20 \mathrm{~m}$ of clayey sedimentary rocks. The permeabilities of the coal aquifers are almost certainly fracture controlled and therefore highly directional; unfortunately, sufficient tests to evaluate the directional variation of permeability have not been made. Pumping tests (Van Voast, 1974, p. 9) indicate transmissivity values of about $12.4 \mathrm{~m}^{2} /$ day (1,000 gpd/ $\mathrm{ft}$ ) for the upper seam and $6.2 \mathrm{~m}^{2} /$ day $(500 \mathrm{gpd} / \mathrm{ft}$ ) for the lower seam. Storage coefficients were estimated as $5 \times 10^{-5}$ and $2 \times 10^{-5}$ for the upper and lower seams, respectively, when fully saturated. Van Voast also estimated a flow of $150 \mathrm{~m}^{3} /$ day $(40,000 \mathrm{gpd})$ into the mine area, of which $95 \mathrm{~m}^{3}$ $(25,000 \mathrm{ga} 7)$ or more may represent upward leakage from the lower seam.

Premining piezometric levels for the Anderson-Dietz No. 1 seam (the $D-1$ coal of Van Voast) showed an eastward gradient of about $3.8 \mathrm{~m} / \mathrm{km}$ in the mine area. These levels represented an artesian condition throughout most of the aquifer, except for a high spot in the coal in the southern part of the 
present (1975) mine. Artesian heads were as much as $12 \mathrm{~m}$ above the top of the coal in the final mine area. Response of the piezometric surface to the excavation of the first cut at the Decker mine in 1972 was almost immediate, and, in the first year and a half of mining, water levels declined almost $8 \mathrm{~m}$ in that part of the aquifer, which was enclosed by the first cut and therefore isolated from the recharge area, and about $4 \mathrm{~m}$ near the western perimeter of the final pit boundary (Van Voast, 1974, figs. 6, 8).

\section{GEOTECHNICAL INVESTIGATIONS}

\section{Methods of investigation}

An early part of this study was the determination of the geotechnical characteristics of highwalls in the Decker, Big Horn, and Welch mines (fig. 2). This work was started in September 1974. Because of the availability of fresh face exposures with a variety of orientations, a large number of observations were made at the Decker mine (fig. 3). More 1imited investigations were made at the Big Horn and Welch mines.

Geotechnical characteristics investigated at each location in the highwalls include slope angles and heights, bed thicknesses, fracture orientations and spacings, and distribution of rock types. Also, samples for physical-property testing were collected.

Stations were set up at intervals along the pit wall in the Decker mine. Closeup Polaroid photographs (covering an area of the wall approximately 2 by $3 \mathrm{~m}$ ) were taken of the area where joints could be reached with a Brunton compass; the identifiable fracture sets were marked on the photos, and the orientation and spacing data were recorded on 5- by 8-in. index cards. A $35-\mathrm{mm}$ camera with a $24-\mathrm{mm}$ wide-angle lens was used to photograph the entire height of a bench, including the area shown in the closeup. These wide-angle photographs were used to extend the information shown in 
Figure 3.--Plan of the Decker mine as of June 1975 showing mapping and sampling locations. Section $\underline{A}-\underline{A}^{\prime}$ shows a typical pit slope.

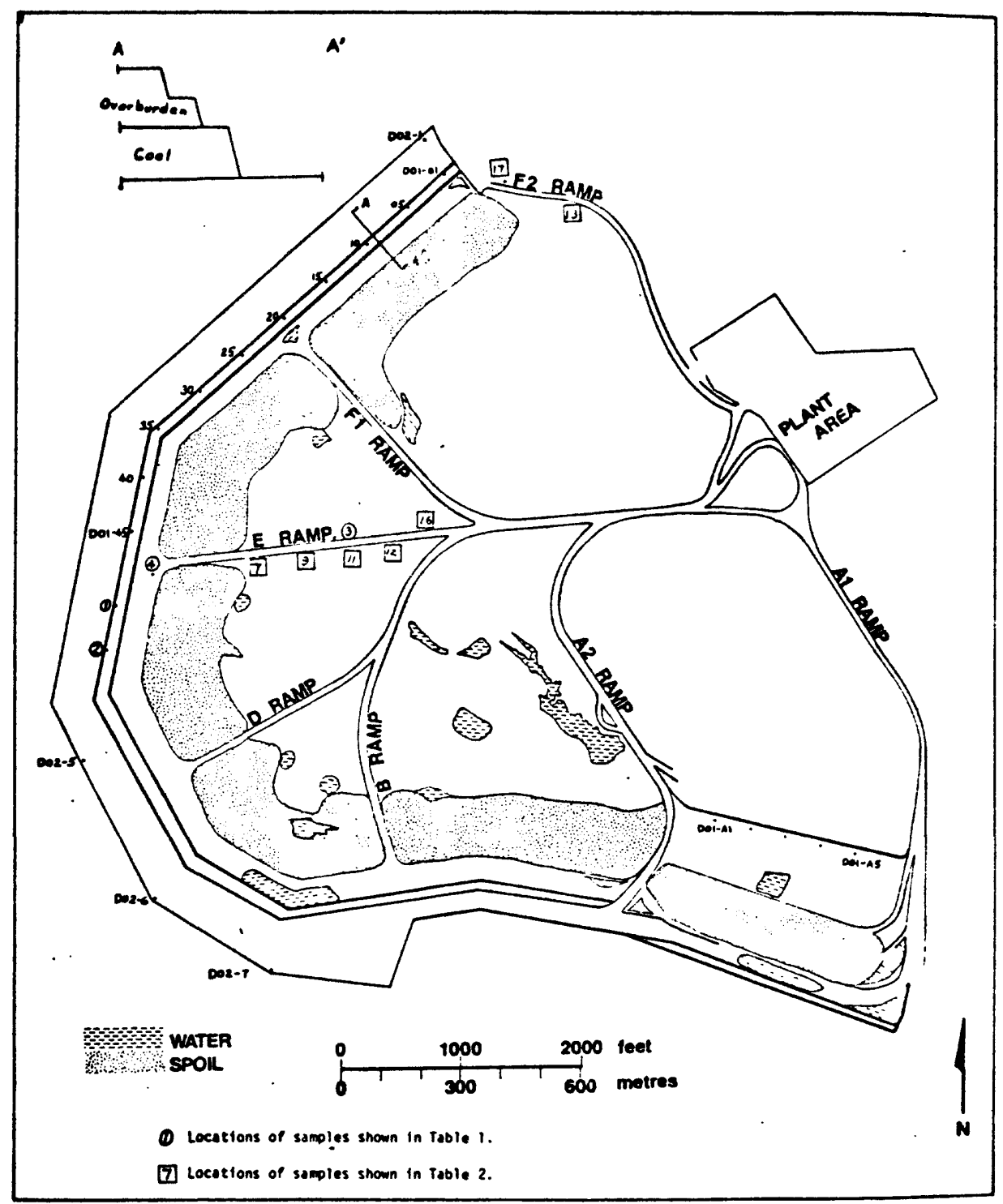


the closeup photos. Initially, a 4-m stadia rod with $1-\mathrm{cm}$ graduations was used in both photographs for scale. Later, we used a 13.5-m segmented aluminum stadia rod of our design. When this rod is used with the wideangle lens we are able to measure bed thickness, fracture spacing, and slope height, as well as to extend the data from the closeup photographs along or up the steep slopes (up to $90^{\circ}$ ) encountered in the mines. At first, sampling stations were set up at approximately $30-\mathrm{m}$ intervals along the pit wall, and 45 stations, starting at the northeast end of the pit, were mapped (fig. 3). In order to sample more of the rock mass in less detail it was decided to increase the spacing to about $90 \mathrm{~m}$, and eight stations on the west and southwest sides of the pit were mapped at this spacing. Several stations were located on slopes on ramp roads (fig. 3 ). Operations at the Decker mine have so far prevented us from studying the highwall at the south end of the pit.

Attitudes and spacing of joints

In order to reduce the inherent bias from projecting fracture information obtained only in the mines and to better estimate regional fracturing, data were also collected at 88 outcrop locations within the $2,400-\mathrm{km}^{2}$ study area. A total of 568 fracture attitudes and spacings was recorded; these were nearly evenly divided between the pits and the outcrops.

The attitudes of joints were compiled on several equal-area diagrams and plotted on figure 2 to show changes from one location to another. Besides bedding, which is a pervasive plane of weakness, the predominant joint set in the study area strikes N. $45^{\circ} \mathrm{W}$. and dips $87^{\circ} \mathrm{NE}$., which parallels most of the tributary drainages to the Tongue River. 0ther prominent fractures strike $\mathrm{N} .37^{\circ} \mathrm{E}$. and $\mathrm{N} .13^{\circ} \mathrm{E}$; ; both are nearly vertical. In general, there appears to be little variation in joint directions for the 
several areas when compared to each other or to the total of all the fractures measured. The relative abundance of joint sets may vary from one area to another, but this may be largely a function of sample size. Also, distinct concentrations appear in some of the equal-area plots representing smaller areas; some of these concentrations disappear when combined with plots representing larger areas.

Spacing of joints in the Fort Union Formation varies with lithology. Coal is the most closely jointed material, and upon exposure to air it slakes rapidly to cubes less than $4 \mathrm{~cm}$ on a side. Some massive sandstones and soft but massive claystones and siltstones, on the other hand, have joint spacings of greater than $0.5 \mathrm{~m}$. The spacing of fractures controls highwall deformation; this is discussed further in the section on material characterization.

\section{Laboratory investigations}

The determination of engineering properties of the coal and overburden rocks in the Powder River Basin was necessary to make quantitative predictions of the behavior of existing and proposed highwalls. Samples were collected for physical-property tests, including density, unconfined-, and confined-compression testing; direct shear tests; and clay-mineralogy, grain-size, and several index tests, including Brazilian tension, point load, and Schmidt hammer. Some of these laboratory tests have been completed, while others are pending.

Samples of coal and overburden were taken from four locations in the Decker mine (fig. 3) for physical-property testing. Sampling problems were encountered, as many rocks were simply too weak to permit an adequately sized piece to be removed from the field site. Other blocks failed during drilling and were unusable for many of the tests. Attempts to obtain 
suitable cores for uniaxial or triaxial testing from the shale at location 2 (fig. 3) were unsuccessful, because the rock crumbled rapidly after it was removed from the pit wall.

The physical-property tests were performed by M. P. Fahy at the University of Colorado, Boulder, Colo. The results are summarized in table 1. The triaxial tests were made in Hoek-type cells at confining pressures of from 0 to $10,300 \mathrm{kN} / \mathrm{m}^{2}\left(0-1,500 \mathrm{lb} / \mathrm{m}^{2}\right)$. Specimens were cut from the blocks with diamond core barrels, giving 20.8-mm and 22.9-mmdiameter cores, which were then trimmed to a length-to-diameter (L/D) ratio of approximately 2 to 1 . Figure 4 shows a typical triaxial test plot. The complete set of triaxial and uniaxial test curves is given in Fahy and Smith (1976, apps. I, II).

Note that because of the sampling problems mentioned above, Young's moduli, peak compressive strengths, and residual compressive strengths determined from the triaxial tests are biased toward the more competent rocks. Poisson's ratios, which were determined in uniaxial tests, would be similarly biased.

Graphs of peak and residual strengths vs. confining pressure for several rock types are shown in figure 5, and graphs of Young's modulus vs. confining pressure are shown in figure 6 . Many of these relationships were nonlinear at low confining pressures, although most of them approach linearity at higher confining pressures. Young's modulus increased with confining pressure for all rocks except coal. These data show considerably more scatter at low confining pressures (less than $\left.3,000 \mathrm{kN} / \mathrm{m}^{2}\left(450 \mathrm{lb} / \mathrm{in}^{2}\right)\right)$, which is the range applicable to most present surface excavations in the region. The behavior at higher levels of 

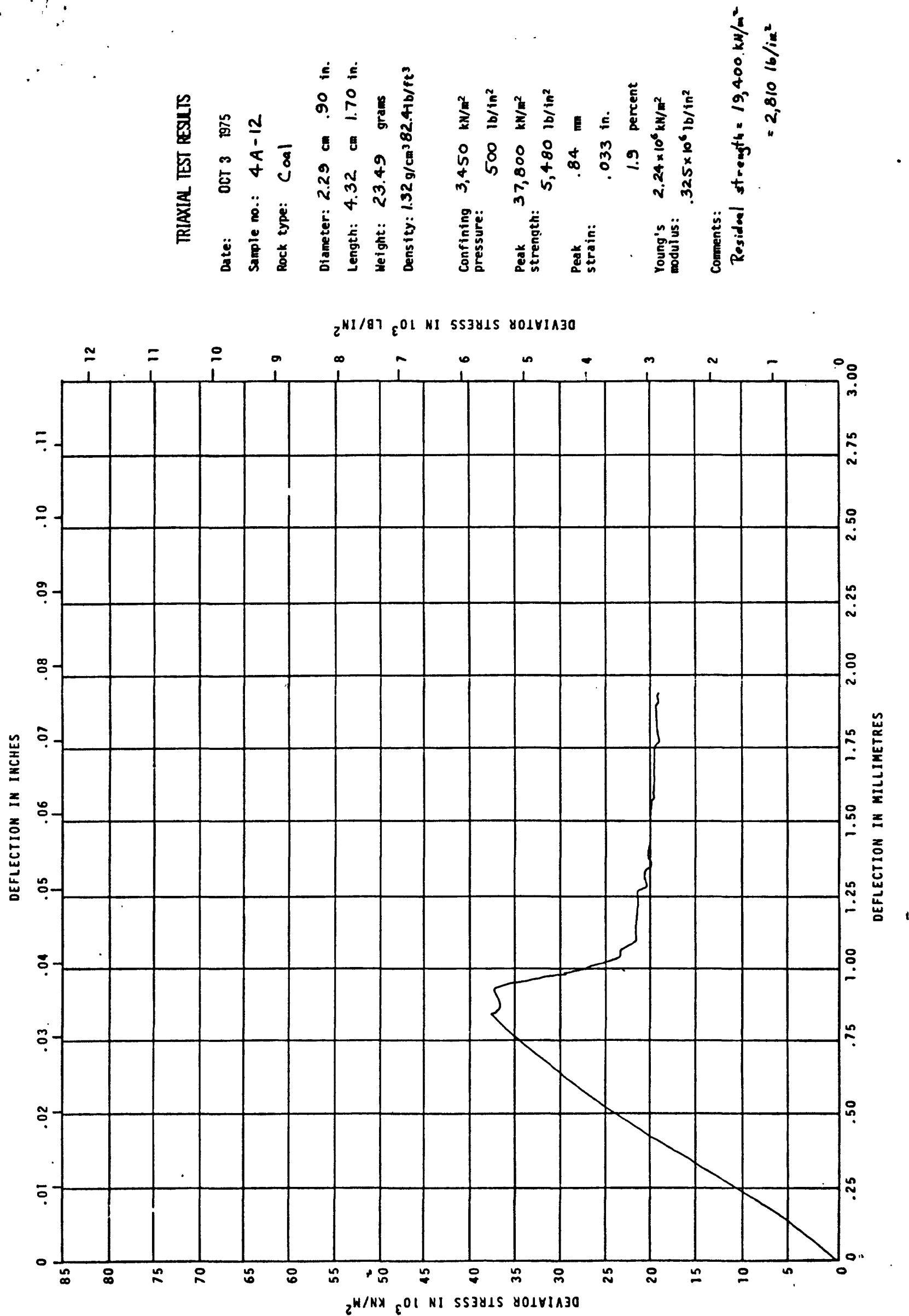

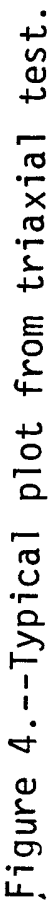



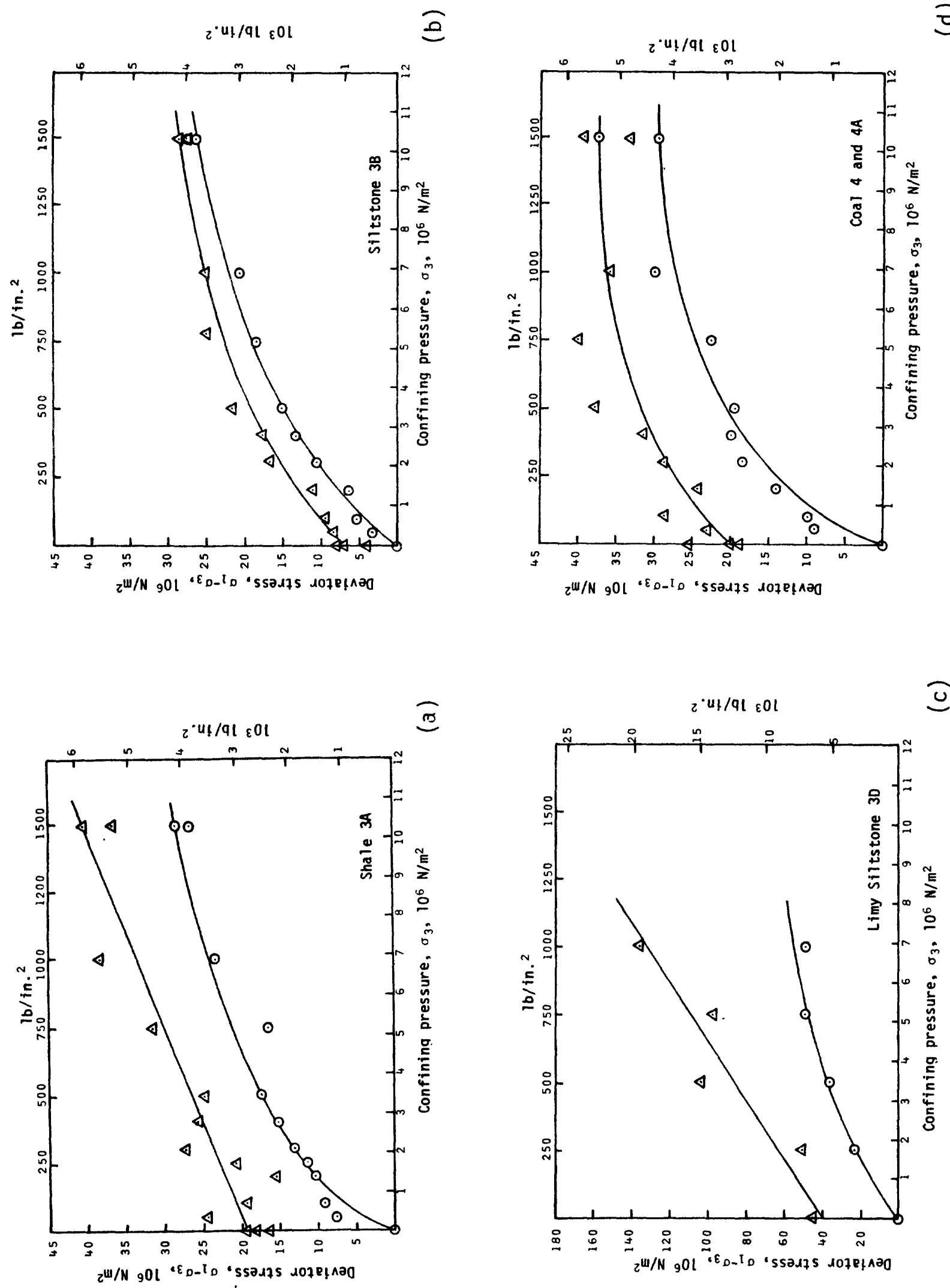

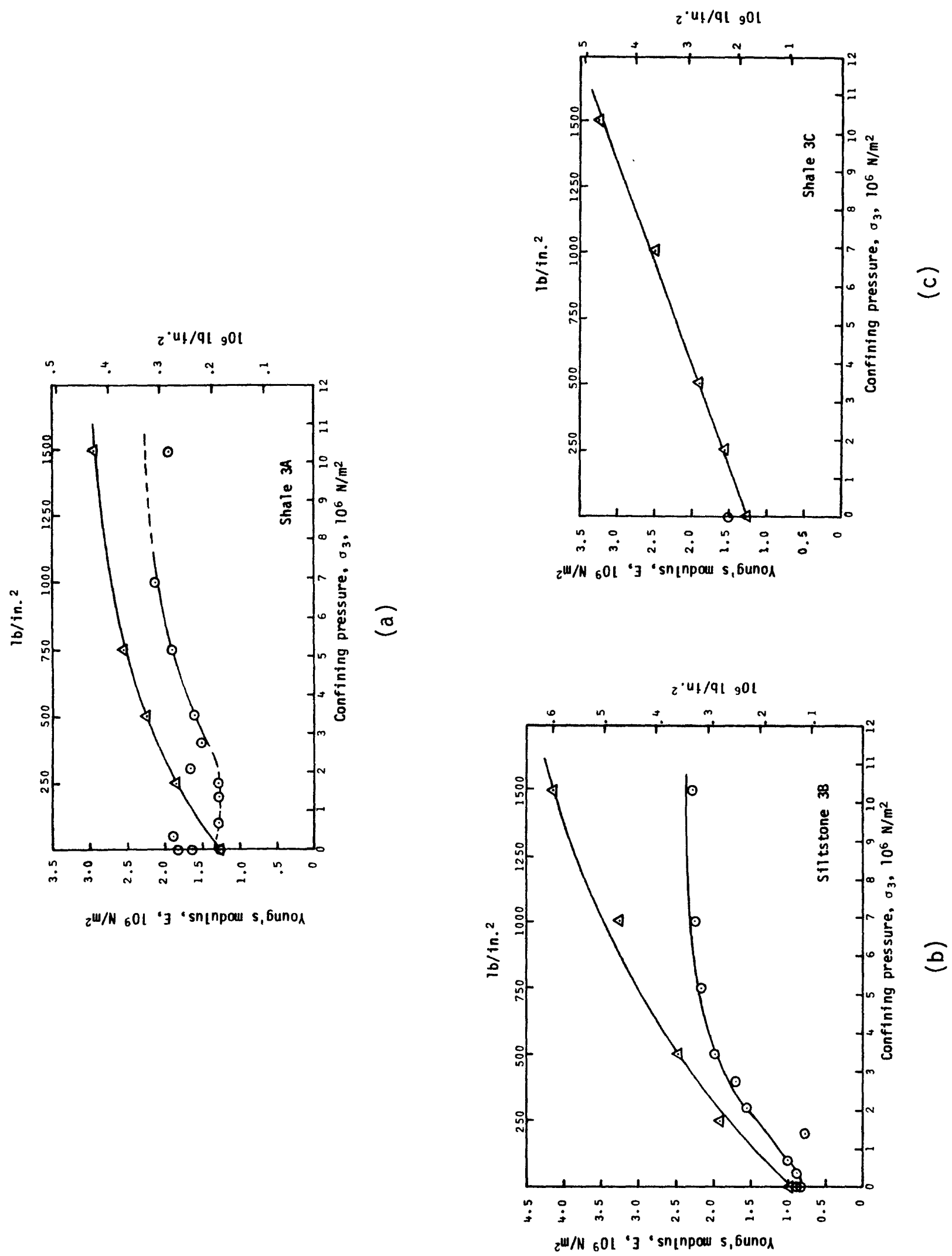

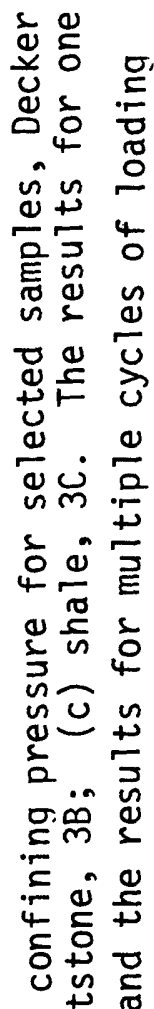

도은

的洔

돌.

모일

$\because$ 东

ํㅣㅇ

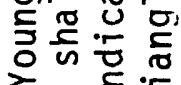

两

40

ᄃ...

$\therefore$ 웡

प्र

证 西

을 물

1 ... . .

๑..$ّ$

U

ठั

뜬 
confining pressure will be more useful in estimating the behavior of these or similar rocks at greater mining depths.

In the uniaxial testing, 13 tests for Poisson's ratio were run on six rock types, and most showed large discrepancies between tests on different cores from the same rock type. Three of these tests gave indicated values of Poisson's ratio greater than 0.5 , indicating that considerable dilatancy occurred during the test.

Small disks left after trimming cores for the uniaxial and triaxial tests and disks cut from cores too short for these tests were used for the Brazilian tension test. In most cases the disks were loaded perpendicular to the bedding planes, but for several rock types some specimens were also loaded parallel to and at oblique angles to the bedding. All the coal samples and the sandstone samples exhibited apparent brittle failure; a sudden drop in applied load occurred as the sample was violently ejected from loading platens. All shale and siltstone samples exhibited apparent ductile failure; a slow decrease in applied load occurred as the sample split in tension. The Brazilian test data generally have larger coefficients of variation $\left(C_{v}=\frac{\text { std. deviation }}{\text { mean }}\right)$ for the various groups than the triaxial test data.

Unconfined compression testing was performed on 11 rock samples from the Decker and the Big Horn mines by A. D. Barnosky and D. M. Worley in the U.S. Geological Survey laboratories (table 2). Point-load tensile strengths and moisture contents were also determined and are shown in table 2. Poisson's ratio in the soft, clay-rich rocks is very sensitive to the magnitude of the axial load; higher values generally occurred at higher axial loads (table 1), and lower values occurred at lower axial loads (table 2). 


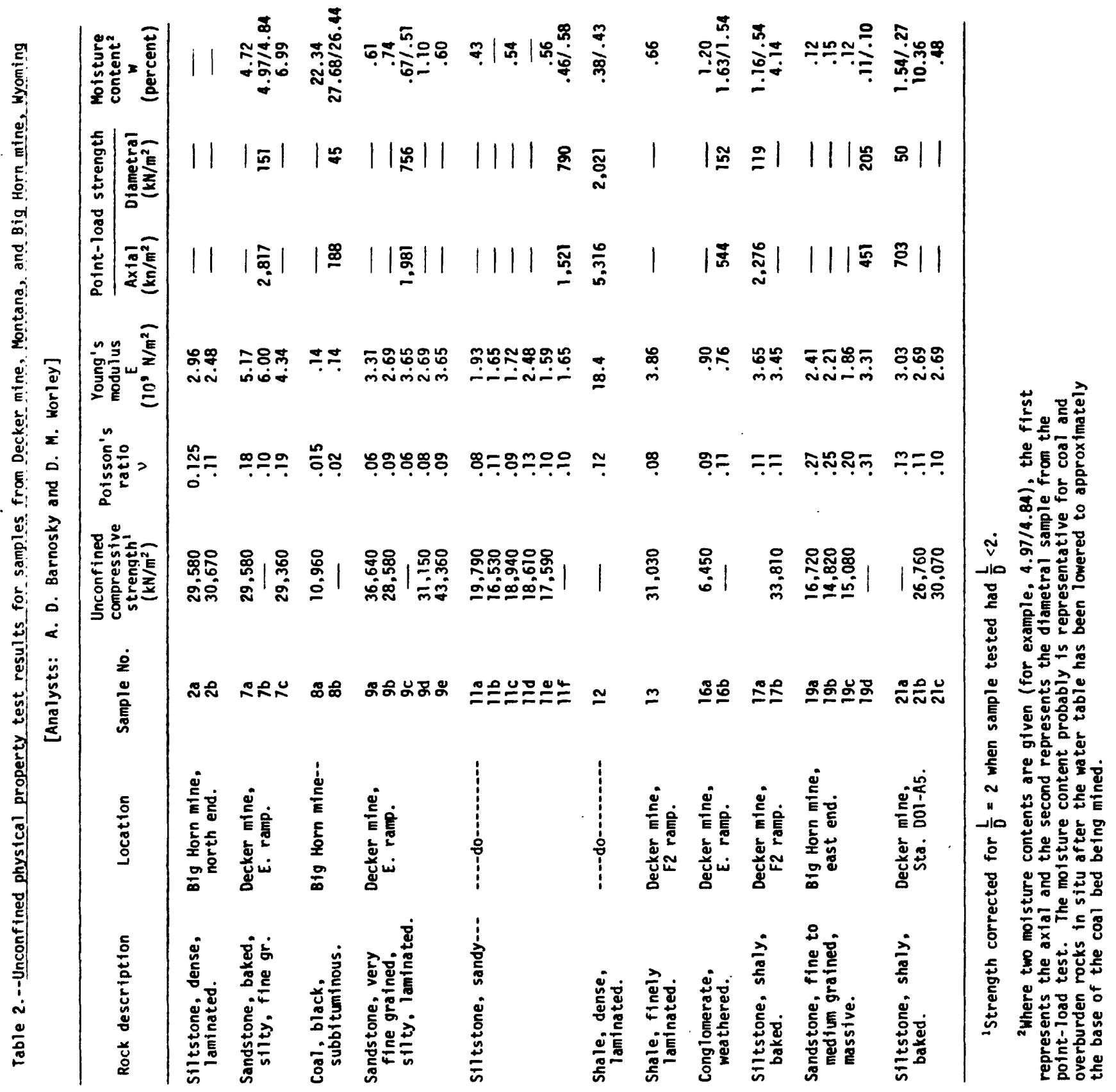


For both the Brazilian and point-load tests, tensile strengths obtained when the sample was loaded perpendicular to the bedding were almost four times higher than those for a loading direction parallel to bedding. Tests oblique to bedding gave intermediate values.

To determine the angle of internal friction, $\phi$, and the cohesion, $c$, a straight line was fit to the values of $\frac{\sigma_{1+\sigma_{3}}}{2}$ versus $\frac{\sigma_{1-\sigma_{3}}}{2}$ at the yield points found in a series of triaxial tests. Since Coulomb's criterion predicts that

$$
\frac{\sigma_{1-\sigma_{3}}}{2}=c \cos \phi+\frac{\sigma_{1+\sigma_{3}}}{2} \sin \phi
$$

this line has an intercept equal to $c \cos \phi$ and a slope $\tan \alpha=\sin \phi$, or $\phi=\sin ^{-1}(\tan \alpha)$. From this information, then, both $\phi$ and $c$ are found. Plots of $\frac{\sigma_{1+\sigma_{3}}}{2}$ versus $\frac{\sigma_{1-\sigma_{3}}}{2}$ for selected samples from the Decker mine, Montana, are shown in figures 7 through 11 . Linear regression fits to the data and the 99-percent confidence limits for the dependent variables are also shown.

The range of values of $\phi$ and $c$ at the 99 -percent confidence level is then found from the predicted slopes and intercepts for each rock type. This range of values of $\phi$ and $c$ is given in table 3. Of course, cohesions can never be less than zero, so for the shale (1) and the limy sandstone (3D) the lower limit on $c$ is zero.

\section{GENERAL OBSERVATIONS ON THE STABILITY \\ OF HIGHWALLS IN THE STUDY AREA}

No large highwall failures were observed in any of the mines examined within the study area. Several small and incipient failures, however, were observed and have led to recognition that highwalls in the area become less stable with time. For example, as shown in figures $12 a$ and $b$, 
Figure 7.--Least squares fit of $\frac{\sigma_{1-} \sigma_{3}}{2}$ vs. $\frac{\sigma_{1+\sigma_{3}}}{2}$ for shale of sample series 1 (table 1). For this correlation, $R=0.96$, the 99-percent confidence range for the intercept $\left(0.27 \times 10^{6} \mathrm{~N} / \mathrm{m}^{2}\right)$ is $-1.9 \times 10^{6}$ to $2.4 \times 10^{6} \mathrm{~N} / \mathrm{m}^{2}$, and the 99-percent confidence range for the slope $(0.60)$ is 0.40 to 0.80 . $10^{3} \mathrm{~Tb} / \mathrm{m}^{2}$

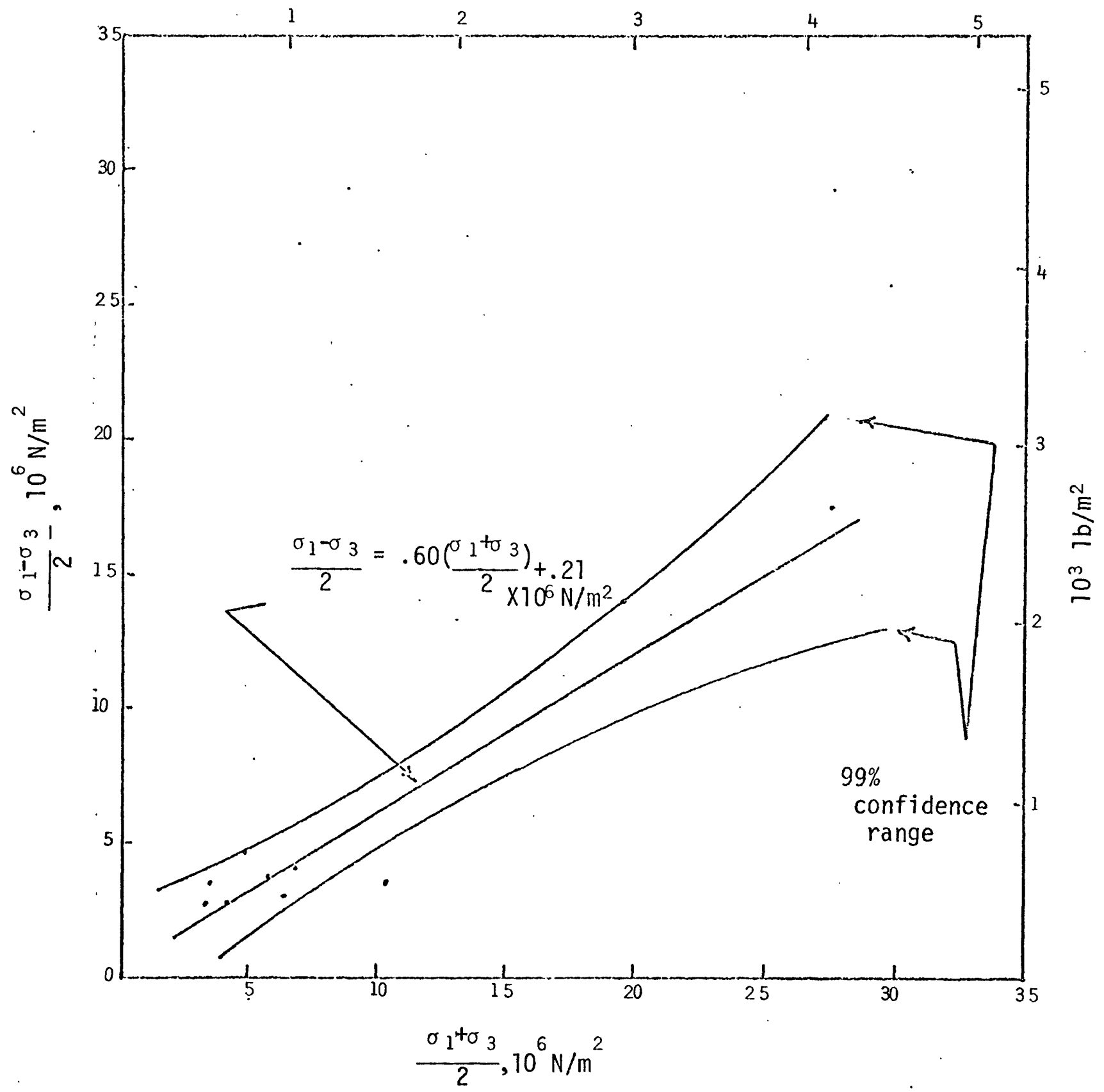


Figure 8.--Least squares fit of $\frac{\sigma_{1} \sigma_{3}}{2}$ vs. $\frac{\sigma_{1}+^{\sigma_{3}}}{2}$ for shate of sample series $3 A$ (table 1). For this correlation, $R=0.96$, the 92-percent confidence range for the intercept $\left(4.56 \times 10^{6} \mathrm{~N} / \mathrm{m}^{2}\right)$ is $2.75 \times 10^{6}$ io $6.37 \times 10^{6} \mathrm{~N} / \mathrm{m}^{2}$, and the 99-percent confidence range for the slope $(0.48)$ is 0.37 to 0.60 . $10^{3} \mathrm{lb} / \mathrm{in}^{2}$

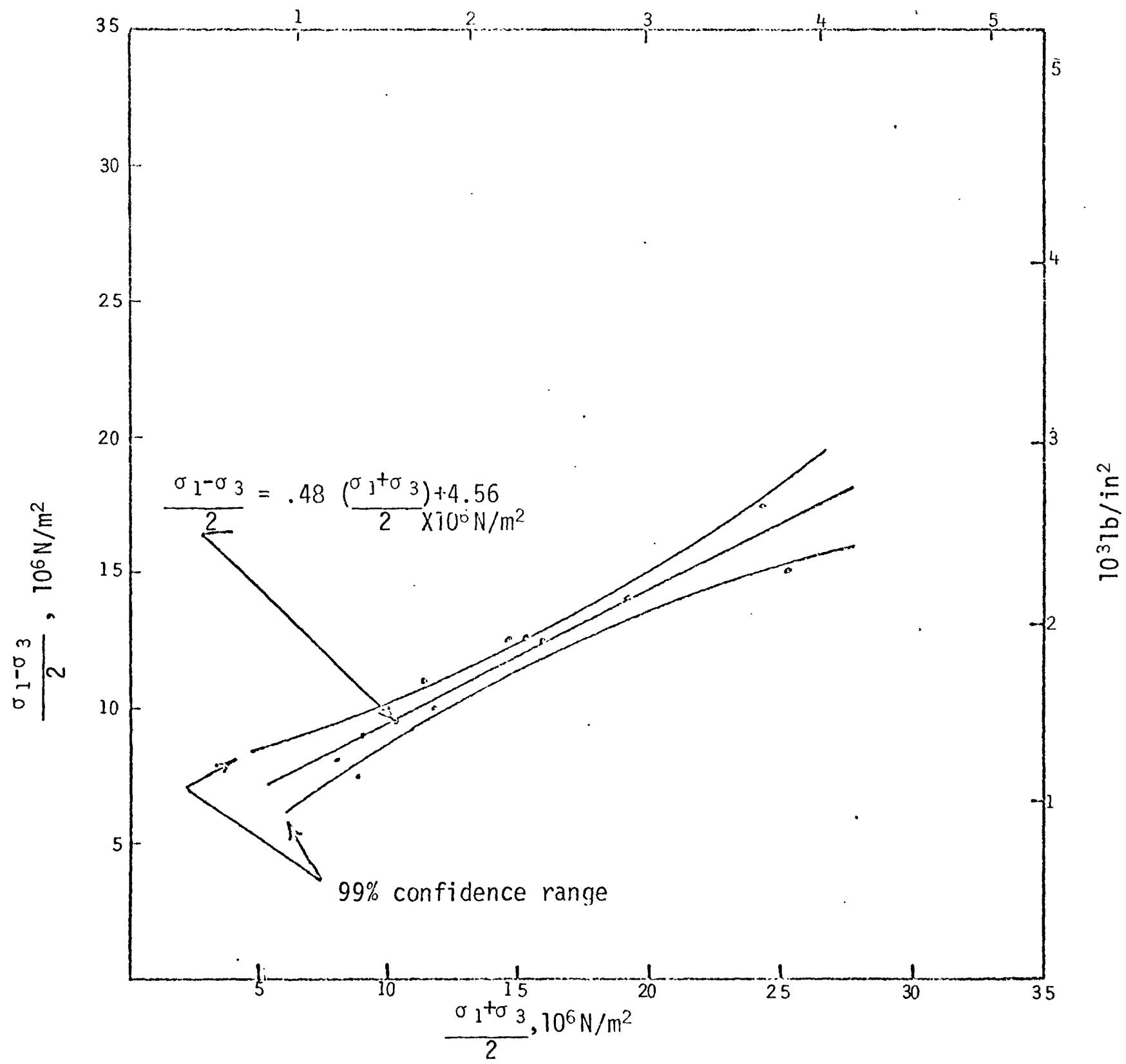


Figure 9.--Least squares fit of $\frac{\sigma_{1-\sigma_{3}}}{2}$ vs. $\frac{\sigma_{1+\sigma_{3}}}{2}$ for siltstone of sample series $3 B$ (table 1). For this correlation, $R=0.98$, the 99-percent confidence range for the intercept $\left(1.95 \times 10^{6} \mathrm{~N} / \mathrm{m}^{2}\right)$ is 0.90 to $3.0 \times 10^{6}$ $\mathrm{N} / \mathrm{m}^{2}$, and the 99-percent confidence range for the slope $(0.52)$ is 0.43 to 0.60 .

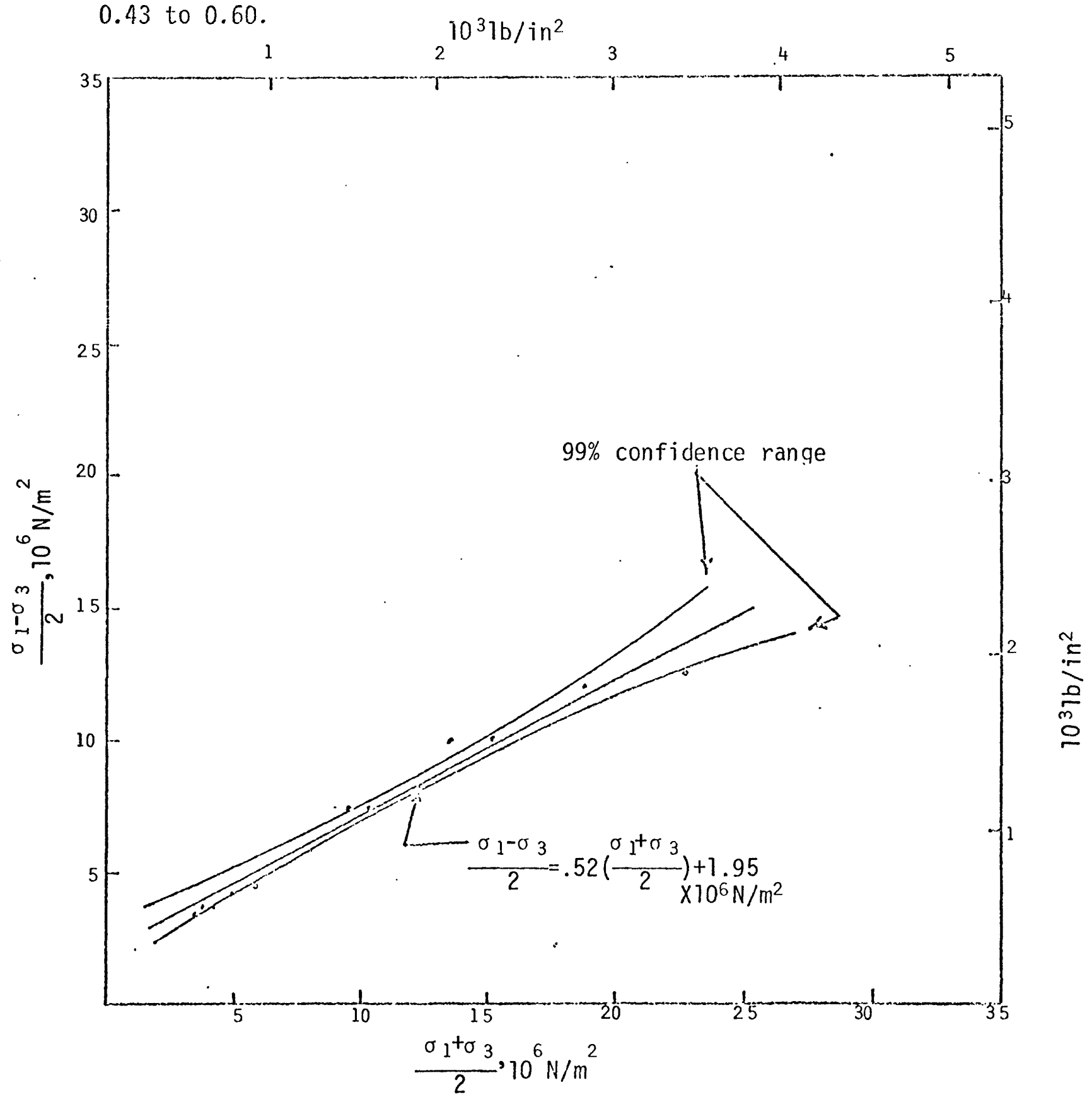


Figure 10.-..Least squares fit of $\frac{\sigma_{1}-\sigma_{3}}{2}$ vs. $\frac{\sigma_{1+1} \sigma_{3}}{2}$ for sandstone of sample series 30 (table 1). For this corretation, $R=0.99$, the 99-percent confidence range for the intorcept $\left(2.63 \times 10^{6} \mathrm{~N} / \mathrm{m}^{2}\right)$ is -1.57 to $6.83 \times 10^{6}$ $\mathrm{N} / \mathrm{m}^{2}$, and the 99-percent confidence range for the slope $(0.87)$ is 0.78 to 0.97 .

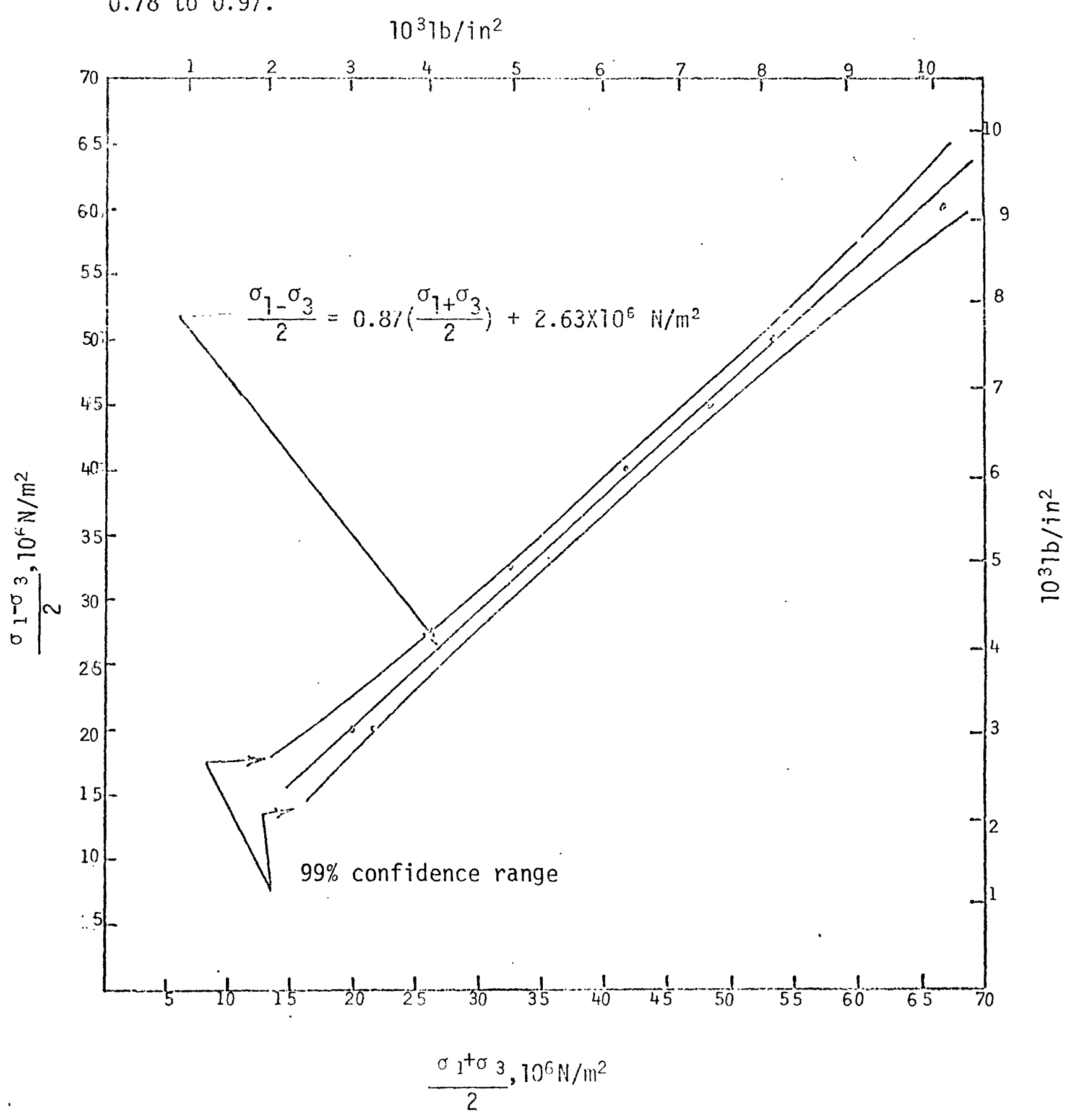


Figure 11.--Least squares fit of $\frac{\sigma_{1-\sigma_{3}}}{2}$ vs. $\frac{\sigma_{1+} \sigma_{3}}{2}$ for coal of sample series 4 (table 1). For this correlation, $R=0.89$, the 99-percent confidence range for the intercept $\left(5.26 \times 10^{6} \mathrm{~N} / \mathrm{m}^{2}\right)$ is $1.32 \times 10^{6}$ to $9.19 \times 10^{\circ} \mathrm{N} / \mathrm{m}^{2}$, and the 99-percent confidence range for the slope $(0.52)$ is 0.29 to 0.74 .

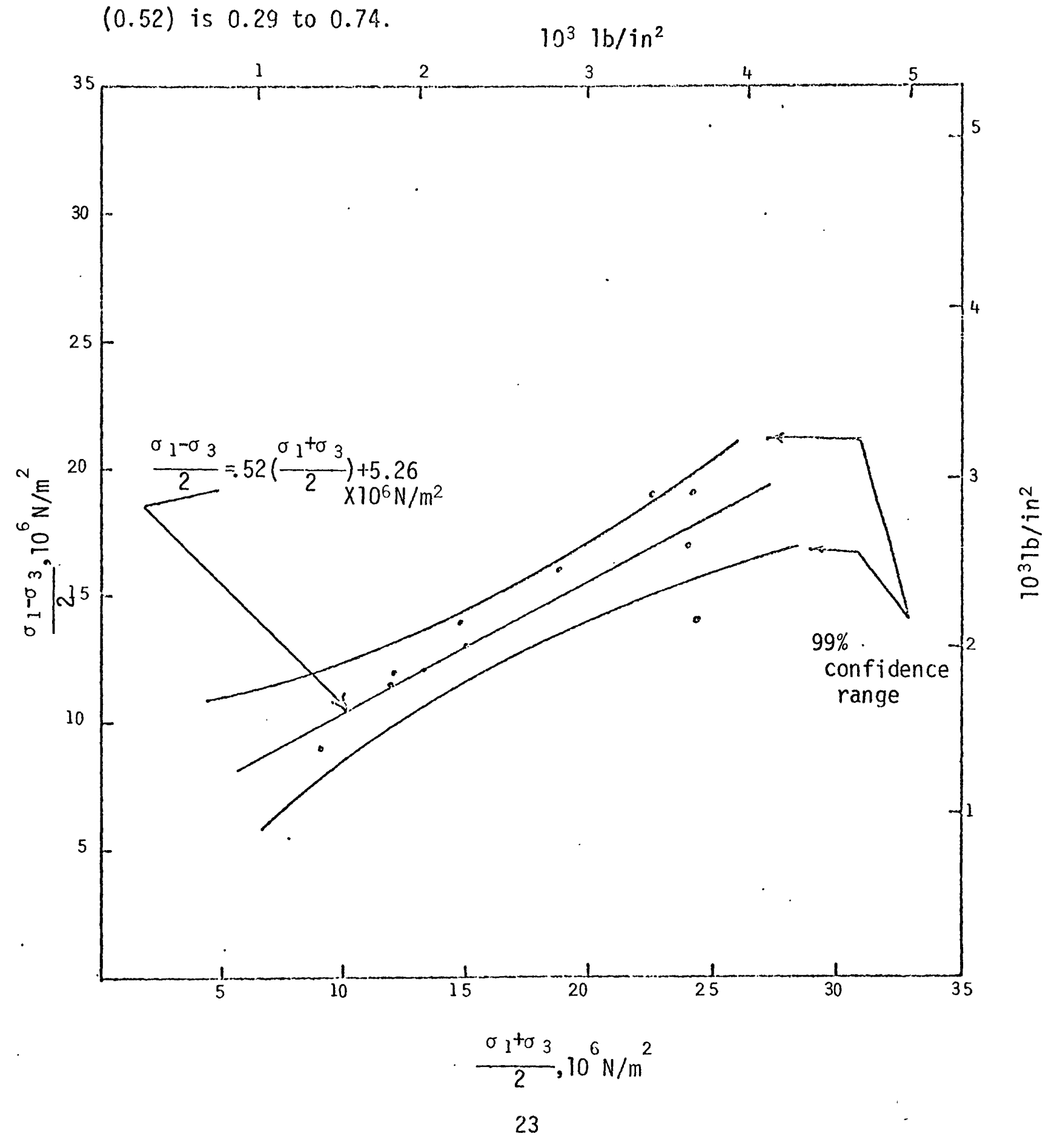


Table 3.--Range of values of $\phi$ and $c$ calculated at the 99-percent confidence level

\begin{tabular}{|c|c|c|c|c|c|c|}
\hline \multirow[b]{2}{*}{ Kock type } & \multicolumn{3}{|c|}{ Range of $\phi$} & \multicolumn{3}{|c|}{ Range of $c$} \\
\hline & $\begin{array}{l}\oint^{\circ} \\
\text { lower }\end{array}$ & $\begin{array}{c}\phi^{\circ} \\
\text { predicted }\end{array}$ & $\begin{array}{l}\phi^{\circ} \\
\text { upper }\end{array}$ & $\begin{array}{c}c-\text { lower } \\
\mathrm{N} / \mathrm{m}^{2}\end{array}$ & $\begin{array}{c}\mathrm{C} \\
\text { predicted } \\
\mathrm{N} / \mathrm{m}^{2}\end{array}$ & $c-$ upper \\
\hline Shale (1) -........ & 23.36 & 36.58 & 52.70 & $-3.21 \times 10^{6}$ & $0.26 \times 10^{6}$ & $2.58 \times 10^{6}$ \\
\hline Shate $(3 A) \cdots$ & 21.44 & 29.03 & 37.23 & $3.45 \times 10^{6}$ & $5.55 \times 10^{6}$ & $6.85 \times 10^{6}$ \\
\hline $\begin{array}{l}\text { Limy sand- } \\
\text { stone (3D). }\end{array}$ & 51.26 & 60.46 & 75.93 & $-6.48 \times 10^{6}$ & $5.33 \times 10^{6}$ & $10.91 \times 10^{6}$ \\
\hline Siltstone (3B)--- & 23.47 & 31.33 & 36.87 & $1.13 \times 10^{6}$ & $2.28 \times 10^{5}$ & $3.32 \times 10^{5}$ \\
\hline Coar (4) & 16.86 & 31.30 & 47.73 & $1.96 \times 10^{6}$ & $6.16 \times 10^{6}$ & $9.60 \times 10^{6}$ \\
\hline
\end{tabular}


tension cracks and local failures are developed in benches on highwalls after 3 to 6 months of exposure. This suggests a degradation of rock strength with time, which could be caused by desiccation or overconsolidation.

\section{Possible effects of desiccation on stability}

A possible explanation for highwall weakening is desiccation. Upon exposure to the air, many of the clay-rich rocks as well as the coals dry out, becoming intensely fractured. This was commonly observed on freshly cut surfaces on the highwall and in unwrapped laboratory samples. Such behavior was noted by Taff (1909, p. 133). Referring to coal of the Tongue River Formation [sic], he stated that once exposed "it undergoes a rapid change by the loss of free moisture, which causes it to check or crack in various directions." Thus, desiccation with fracturing on a fresh highwall cut would provide new surface area for desiccation and further cracking, leading eventually to a weakening of the highwall and failure.

\section{Possible effects of overconsolidation on stability}

Another possible weakening mechanism is rebound of overconsolidated rock in the highwalls. This phenomenon has been widely reported in the Fort Union Formation outside the Powder River Basin, but not within the basin.

Many of the rocks in the study area are similar to so-called "clay shales," a type of rock that is particularly apt to be overconsolidated (Bjerrum, 1967; Fleming and others, 1970). If these rocks are highly overconsolidated, then much greater deformations would be experienced after an opening is excavated than would be expected in rocks of lesser consolidation states. For example, Smith and Redlinger (1953) reported 


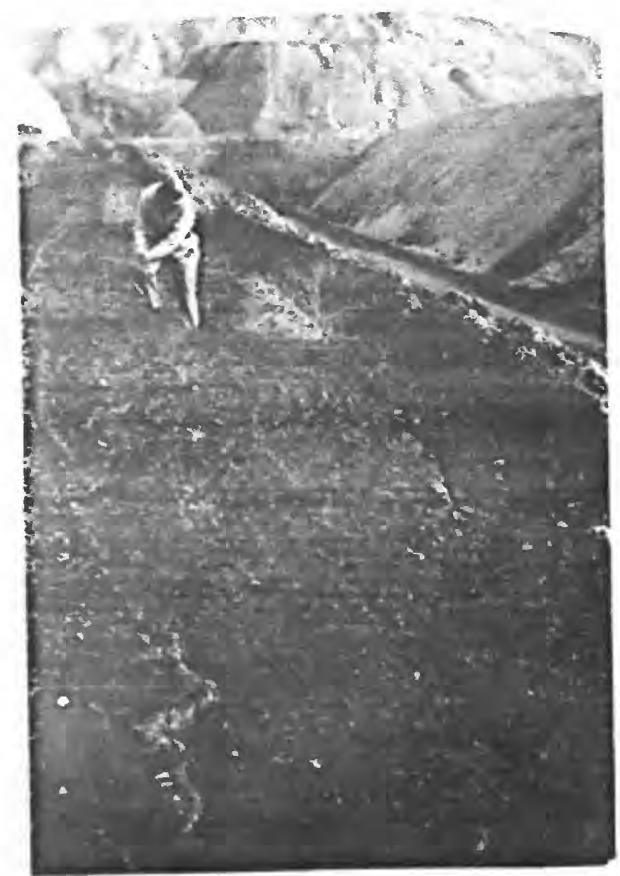

(a)

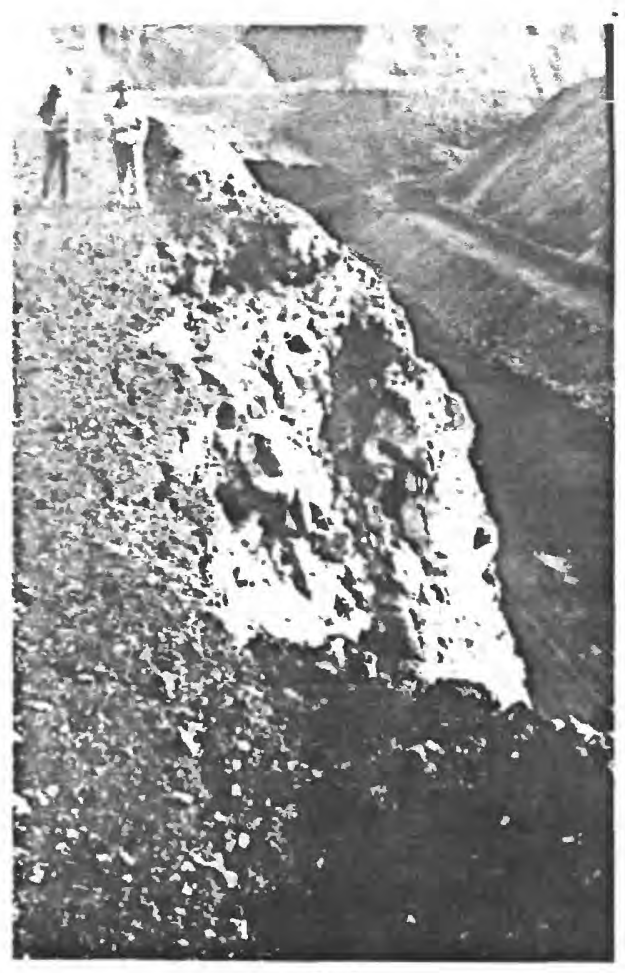

(b)

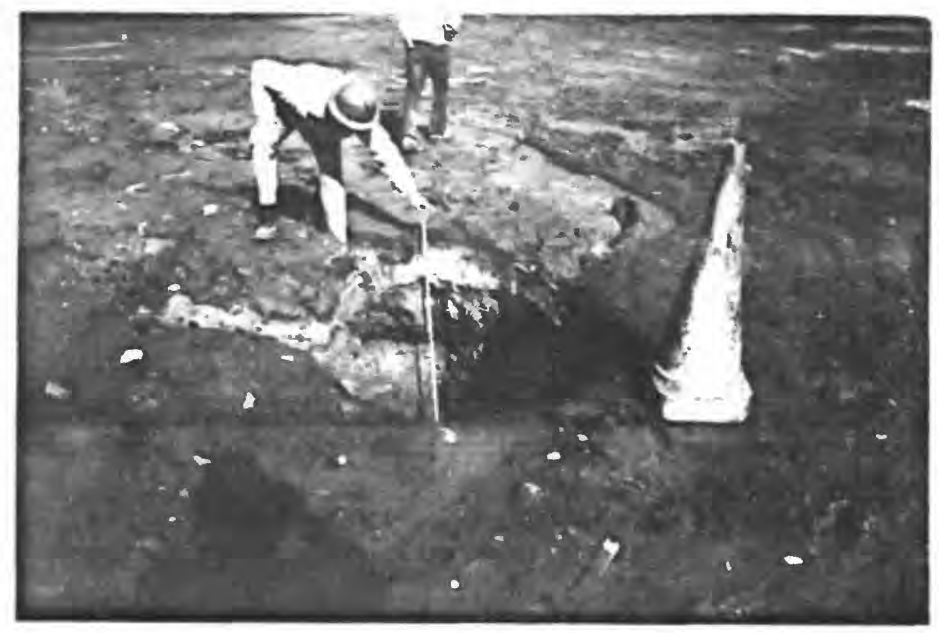

(c)

Figure 12.--Development of minor slope failure: (a) nearly vertical open fissure trending approximately parallel to the slope; (b) small slump failure of a portion of the highwall; (c) piping resulting from channelized surface runoff (tape measure is $2 \mathrm{~m}$ long). 
high horizontal stresses in Fort Union clay shale at the Garrison damsite in west-central North Dakota. Saw cuts (presumably vertical) $7.6 \mathrm{~cm}$ wide and $2.1 \mathrm{~m}$ deep, made in the powerhouse area, closed in about 24 hours (Smith and Redlinger, 1953, p. 65). This deformation was attributed to the release of high lateral stresses that were induced by overburden that was once $457 \mathrm{~m}$ higher than at present. As much as $0.9 \mathrm{~m}$ of rebound was measured in the deepest excavation at Garrison Dam (Underwood, 1967, p. 109). Smith and Redlinger (1953) inferred that the magnitude of rebound of these rocks is dependent upon the rate of unloading. These deformations have an initial abrupt phase, followed by long-term relaxation (Underwood and others, 1964).

Rocks of the Fort Union Formation that are now exposed at the surface in the western Powder River Basin were once buried by hundreds of meters of sedimentary material that has been largely stripped away by erosion. Because exposures of post-Eocene rocks are scarce, it is difficult to estimate accurately the thickness of this cover of Eocene and younger sedimentary deposits; but, according to McKenna and Love (1972, p. 5, fig. 2B), it was approximately $1,200 \mathrm{~m}$ thick in an area $100 \mathrm{~km}$ southeast of Sheridan. Once a maximum thickness was attained, however, the sediments were eroded in a relatively short interval of late Cenozoic time (McKenna and Love, 1972, p. 9).

Under these conditions, overconsolidation might occur in the following manner. Figure 13a illustrates conditions at the time of maximum burial of Fort Union rocks in the western Powder River Basin, presumably in Miocene or Pliocene time. The arrows represent stresses in the rocks; the stresses are reduced vertically but remain relatively high horizontally as the overlying sediments are eroded (fig. 13b). The rocks can deform 


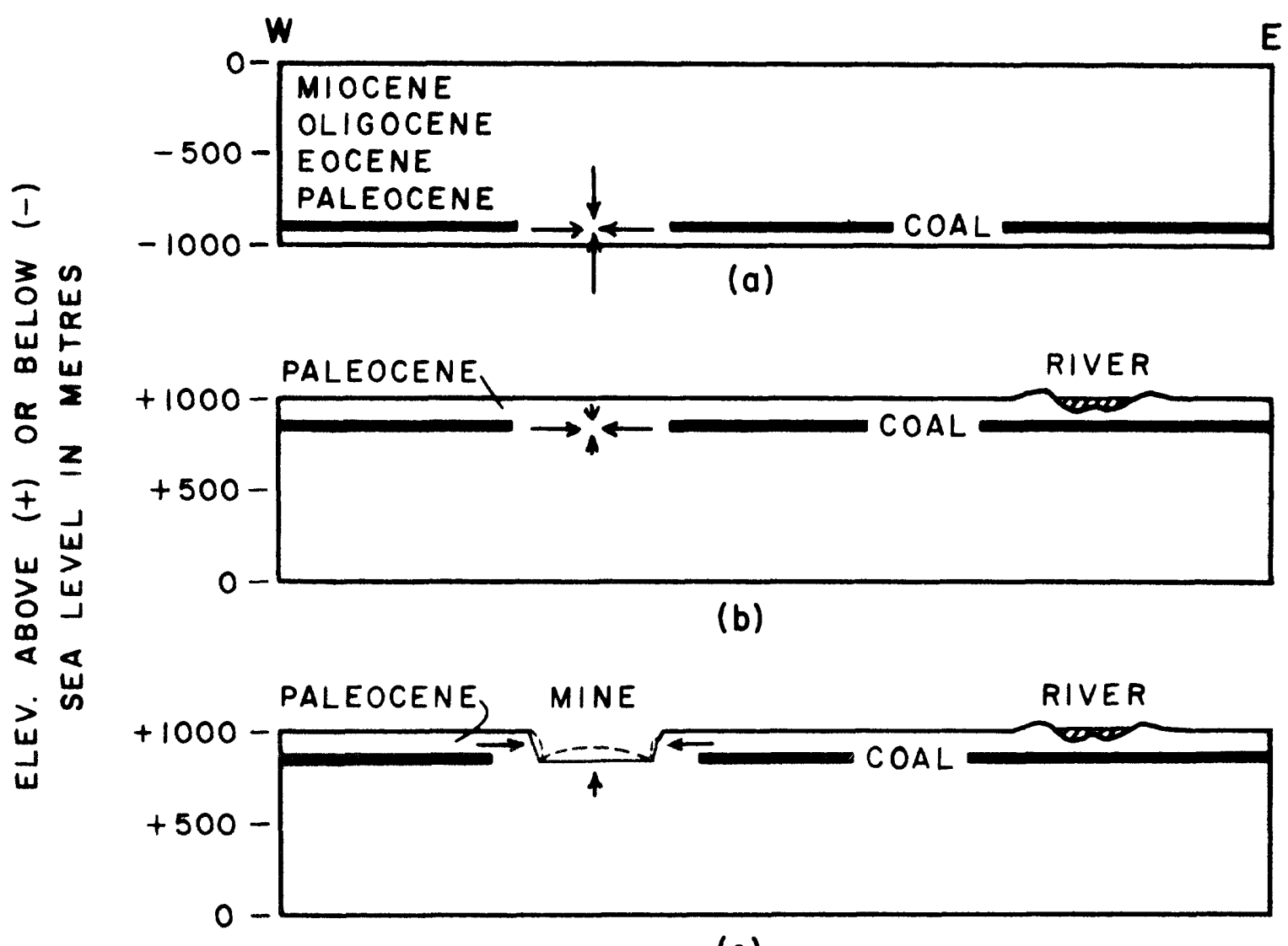

(c)

Figure 13.--Hypothetical sequence of loading and deformational history in the western Powder River Basin. Arrows have no scale but represent the relative magnitude of vertical and horizontal stresses at three stages of development. Thickness of coal and rebound deformations are exaggerated: (a) inferred conditions at the time of maximum burial of Fort Union rocks in the western Powder River Basin; (b) inferred conditions after erosion in late Cenozoic time, showing valley rebound; (c) present conditions after start of mining. Estimates for restored section (a) were taken from McKenna and Love (1972, fig. 2B). 
only if the lateral confinement of the material is reduced. This can be accomplished by an eroding stream, a mine, or a highway cut. Because a stream channel forms more slowly than a mine is excavated, valley walls deform more slowly than mine walls. Magnitudes and rates of deformation (rebound) are complicated; they are controlled by time, geologic history, and material properties as well as by excavation methods.

From the geologic evidence we can calculate approximate values for the magnitudes of the horizontal stresses. The maximum effective vertical stress is estimated to have been approximately $21,000 \mathrm{kN} / \mathrm{m}^{2}\left(3,000 \mathrm{lb} / \mathrm{in}^{2}\right)$, using an average density of $2,372 \mathrm{~kg} / \mathrm{m}^{3}\left(148 \mathrm{lb} / \mathrm{ft}^{3}\right)$ and an overburden thickness of $1,000 \mathrm{~m}$. The effective lateral (horizontal) stress $\left(\sigma_{h}\right)$ due to this vertical loading can be approximated using the formula

$$
\sigma_{h}=\frac{v}{1-v} \sigma_{v}
$$

which permits no lateral deformation during the application of the vertical load $\left(\sigma_{v}\right)$. The average Poisson's ratio $(\nu)$ for the overburden rock samples tested is approximately 0.3. Thus, for these estimated conditions, a maximum horizontal stress of approximately $9,100 \mathrm{kN} / \mathrm{m}^{2}$ $\left(1,3001 \mathrm{~b} / \mathrm{in}^{2}\right)$ may have existed in the rock. Depending upon the subsequent history of the material, and particularly the strength of grain bonding, typical clayey overburden rocks may have retained a significant portion of this applied stress in the form of residual (recoverable) stresses.

Tensile strains generated by lateral expansion of such overconsolidated rock into an excavation might be sufficient to cause fresh fracturing near the slope face. Since such deformation is generally time dependent, fracturing could occur in a progressive manner, leading to eventual slope failure, as shown in figures $12 a$ and $b$. 
Other factors affecting stability

Water also plays a role in highwall stability in the study area. Several cases of piping were observed where water collected in surface depressions above the slope. In one case (fig, 12c), a hole more than $2 \mathrm{~m}(6 \mathrm{ft})$ deep and $1 \mathrm{~m}(3 \mathrm{ft})$ in diameter that resulted from piping was observed within $50 \mathrm{~m}(150 \mathrm{ft})$ of the crest of a highwall. A small slump failure was observed on the highwall below this pipe.

Ground water probably affects slope behavior in ways other than the piping, but the exact extent of this effect is not yet known. One possibility is the progressive consolidation of the coals in response to drawdown caused by mining (Van Voast, 1974). The resulting settlement might cause additional cracking in the overburden, leading again to a progressive highwal1 weakening and eventual failure.

Fracture orientation is a factor in highwall stability. Slopes excavated approximately parallel to steeply dipping preexisting joints that strike $\mathrm{N} .45^{\circ} \mathrm{W}$. and N. $35^{\circ} \mathrm{E}$. would probably be less stable than highwalls that strike in other directions. However, this instability might be advantageous if the amount of explosive for overburden removal could be reduced. Experience could determine whether such an advantage exists.

The spacing of fractures in the highwalls appears to be quite critical, especially as this spacing was observed to decrease with time. Finally, it was noted that pit geometry had some effect. For example, at the Decker mine more raveling of the highwalls was noted at the corner points of the walls than elsewhere. 


\section{Summary of observations}

Though highwalls in the study area are generally stable, the stability of these slopes is time dependent. Thus, the period of time for which a slope is required to be stable is an important design consideration. Also, we emphasize the role of water in highwall stability. Seepage and piping from pools that are allowed to collect above the highwall lead to small failures and during especially wet weather could contribute to large failures.

\section{STABILITY ANALYSES AND PREDICTIONS \\ Method of analysis}

We have calculated safety factors for a typical open-pit design in the Fort Union Formation by the finite-element method. This method was used because (as demonstrated by Wang and Sun, 1970) it gives a better estimate of safety factors for highwalls cut in layered rocks having layers of varying thickness and behavior than can be obtained with limiting equilibrium methods (Bishop, 1955; Morgenstern and Price, 1965).

The finite-element program used for the calculations is nonlinear. It first calculates, for a given set of boundary conditions, a linear elastic solution. Stresses determined in each element are then compared with the stress level necessary for yielding (that is, the point at which the material properties of the element become dependent on stress level). Where yielding occurs, the moduli are reduced and the solution is iterated until equilibrium and the constitutive relations for the system are satisfied. Rapid convergence is achieved through a combination of iteration schemes, discussed in detail by Baligh (1973). 
The yield function used in the program is that suggested by Drucker and Prager (1952) to account for the internal friction and cohesion of rocks and soils. It is essentially a generalization of the familiar Coulomb-Mohr envelope, $\tau=c+\sigma \tan \phi$, where $\tau$ is the shear stress and $\sigma$ is the normal stress on any plane; $c$ is the cohesion (resistance to shear) across this plane; and $\phi$ is the angle of internal friction $(\mu=\tan \phi)$, where $\mu$ is the coefficient of internal friction. This criterion is shown in $\tau-\sigma$ space in figure 14. Specifically, the Drucker-Prager generalization is

$$
f=\sqrt{J_{2}}+\alpha J_{1}=k
$$

where

$$
J_{2}^{\prime}=\frac{1}{6}\left[\left(\sigma_{1}-\sigma_{2}\right)^{2}+\left(\sigma_{1}-\sigma_{3}\right)^{2}+\left(\sigma_{2}-\sigma_{3}\right)^{2}\right]
$$

is the second deviatoric invariant of the stress tensor

$$
\begin{gathered}
\left(\sigma_{1}, \sigma_{2}, \sigma_{3} \text { are principal stresses }\right) \text {; and } \\
J_{1}=\sigma_{1}+\sigma_{2}+\sigma_{3}
\end{gathered}
$$

is the first invariant of the stress tensor. The definition of the constants $\alpha$ and $k$ depends on the type of rock- or soil-deformation test used to determine them. For a triaxial test,

and

$$
\begin{aligned}
& \alpha=\frac{2 \sin \phi}{\sqrt{3}(3-\sin \phi)} \\
& k=\frac{6 c \cos \phi}{\sqrt{3}(3-\sin \phi)}
\end{aligned}
$$

In practice, it is useful to have a measure of the likelihood of slope failure. To this end, a factor of safety for each element is calculated, which is actually a measure of closeness to failure. As shown by Corp, Schuster, and McDonald (1975), the factor of safety in 


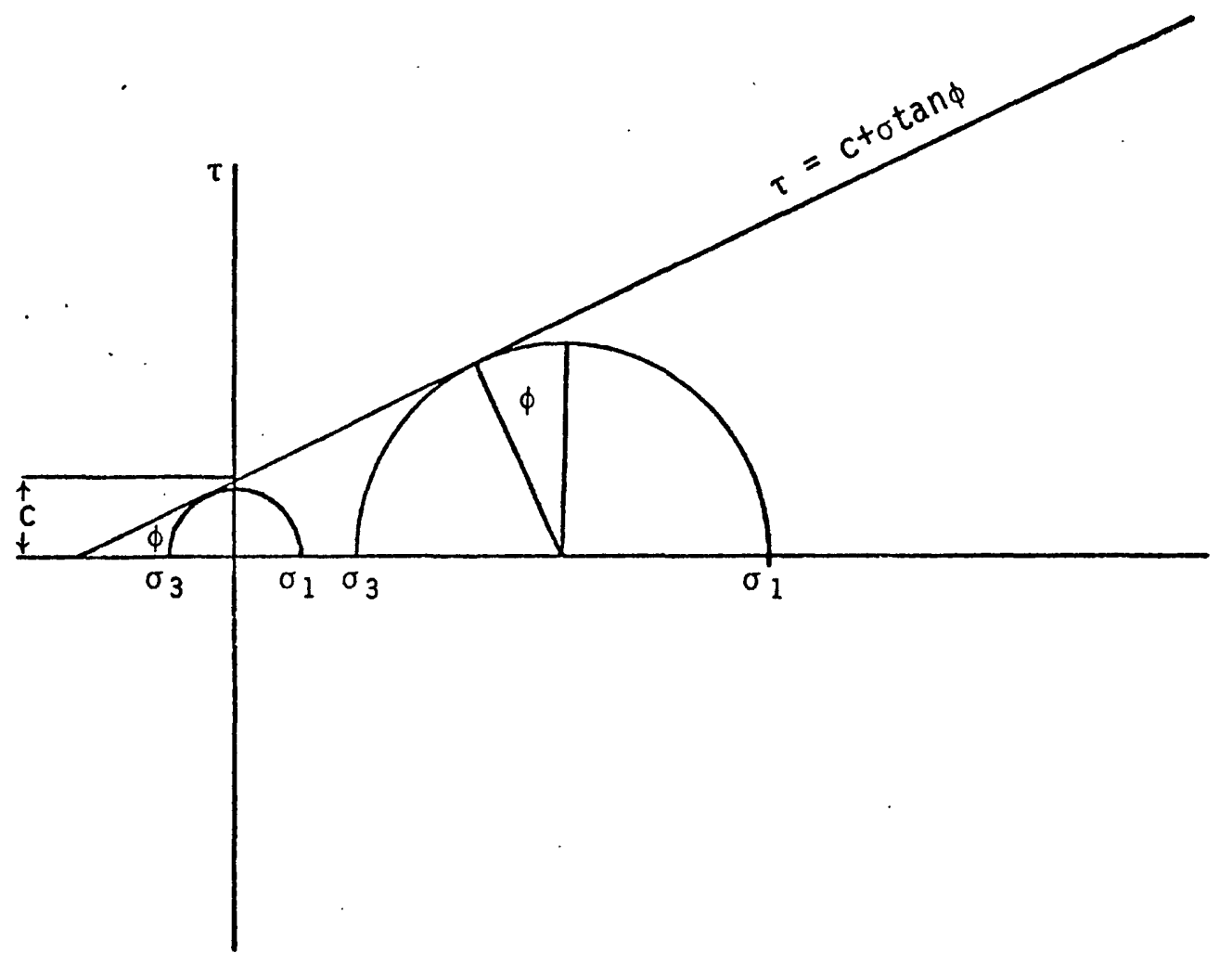

Figure 14.--Coulomb-Mohr envelope $(\tau=c \operatorname{totan} \phi)$ and Moho circles. $\sigma$ is the normal stress; $\tau$, the shear stress; $c$, the cohesion; and $\phi$, the angle of internal friction; $\sigma_{1}$ and $\sigma_{3}$ are the principal stresses of failure.

33 
each element, $i$, is given by

$$
f s_{i}=\frac{k-\alpha J_{1}}{\sqrt{J_{2}^{\top}}}
$$

Equation 7 gives a measure of how close the state of stress in an element is to the yield surface. When $\sqrt{J_{2}}$ is less than $k-\alpha J_{1}, f s_{j}>1$ and the deviatoric stresses are too small to cause yielding. When $\mathrm{fs}_{\boldsymbol{i}}<1$, the deviatoric stresses are too large, and failure occurs in the element being considered.

For the entire slope, as shown by Corp, Schuster, and McDonald (1975),

$$
F_{s}=\sum_{i=1}^{n} \frac{l_{i}}{L} f s_{i}
$$

where $F_{S}$ is the factor of safety for the slope, $f_{s}$ is the factor of safety for element $i$ along the failure surface, $l_{i}$ is the length of the failure surface through the element, $L$ is the total length of the failure surface, and $\mathrm{n}$ is the number of elements intersecting the surface.

Material characterization

Application of the finite-element method of stability analysis requires the determination of a number of rock properties. These are: density $(\rho)$, Young's modulus (E), Poisson's ratio $(\nu)$, the angle of internal friction $(\phi)$, the cohesion $(c)$, and an estimation of the postyield Young's modulus (that is, the slope of the stress-strain curve after yielding).

Laboratory-determined densities and Young's moduli and Poisson's ratios for the rocks collected at the Decker mine, as determined in triaxial and uniaxial tests, are given in tables 1 and 2 . The values of $\phi$ and $c$ for these rocks are given in table 3. Average laboratory property 


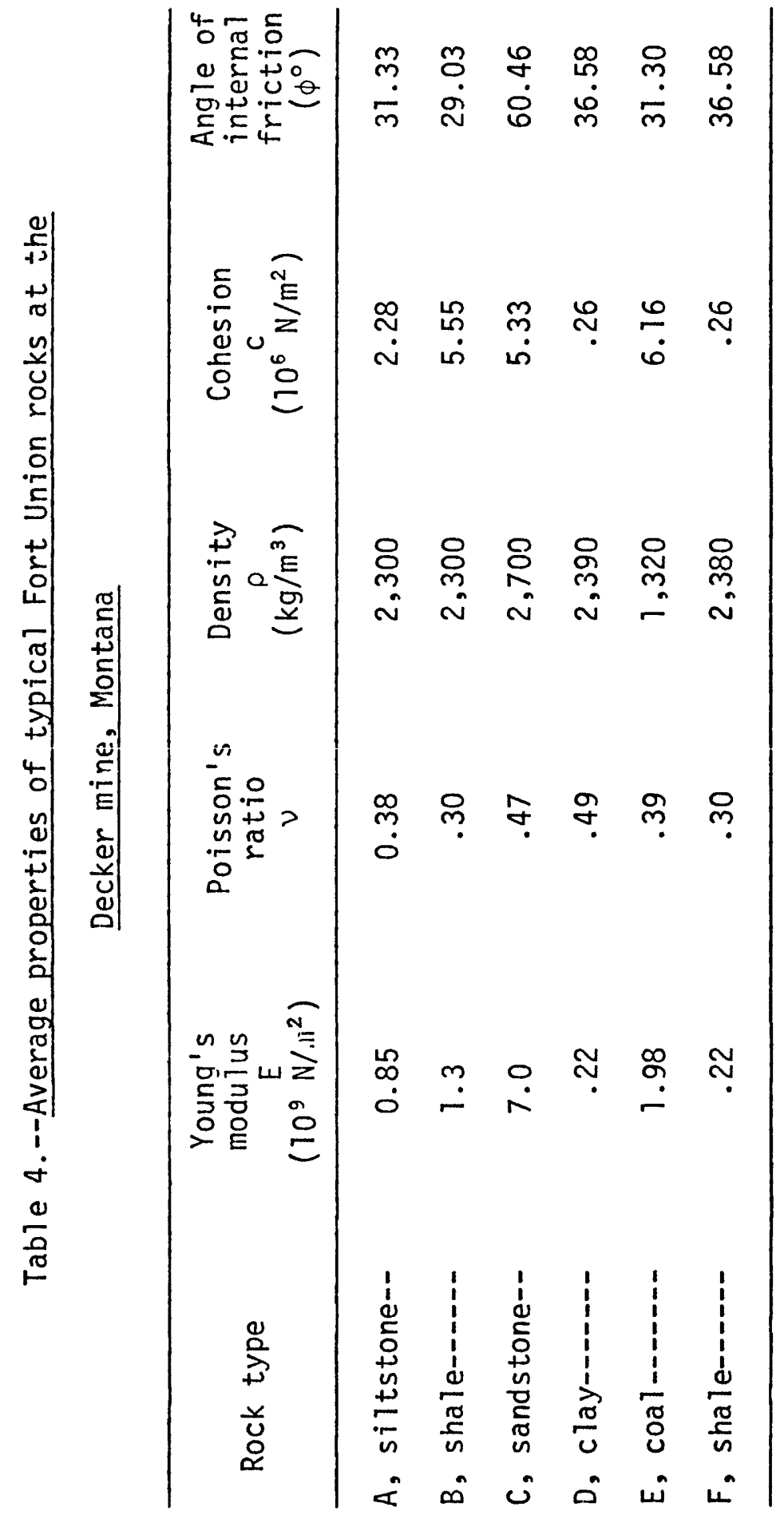


values for these rocks are summarized in table 4 . The cohesions and angles of internal friction are those predicted by linear regression (table 3).

Ideally, the properties in table 4 should be representative of the properties of the rock mass. But, because of the extensive fracturing noted in the field, the rock mass will behave differently under load than will the core-size laboratory sample. Since rock-mass properties have not yet been determined in the field, we have attempted to estimate those properties theoretically.

In highwall faces in the open-pit mines that we examined, most of the rock is closely jointed (average joint lengths are roughly $10 \mathrm{~cm}$ ); the main exceptions are the more massive sandstones and some massive but soft claystones. The shales and siltstones have approximately 1,250 joints per $\mathrm{m}^{3}$, and the more massive sandstones and claystones have approximately 300 joints per $\mathrm{m}^{3}$. As discussed previously, jointing is thought to progress inward from the highwall face, weakening the highwall until it eventually fails.

If, as an approximation, we consider these small joints to be randomly oriented fractures dispersed through the rock, we can use Walsh's (1965a, b, c) theory to estimate the effect of the joints on the rock's elastic properties. Walsh considered the effect of both open and closed fractures on elastic moduli. We will do the same, because in rock masses both types of fractures are present. Open fractures have no sliding friction developed on the fracture faces, whereas sliding friction is developed between faces of closed fractures. 
Walsh found that for rocks with open, narrow fractures of random orientation the effective Young's modulus is

$$
E_{e f f}=E /\left[1+4 / 3^{\pi\left(1-v^{2}\right)} \frac{\bar{c}^{3}}{\bar{V}}\right]
$$

where $E$ is the intrinsic Young's modulus (modulus of unfractured rock), $\bar{c}$ is the average fracture length, and $1 / \bar{V}=N / V$ is the number of fractures within a specified volume. Poisson's ratio for this case is

$$
\nu_{\text {eff }}=\nu \frac{E_{\text {eff }}}{E} \text {, }
$$

where $v$ is the intrinsic (core value) Poisson's ratio.

For rock with closed, randomly oriented fractures obeying Coulomb friction criteria, Walsh derived the effective Young's modulus as

$$
E_{\text {eff }}=E /\left[1+\frac{4 \pi \bar{c}^{3}}{15 \bar{V}}\left[\frac{2+3 \mu^{2}+2 \mu^{4}-2 \mu\left(1+\mu^{2}\right)^{2 / 3}}{\left(1+\mu^{2}\right)^{2 / 3}}\right],\right.
$$

where $\mu$ is the coefficient of sliding friction and the remaining terms are as defined above. Poisson's ratio in this case is

$$
\nu_{\text {eff }}=1 / 2-\left(\frac{1-2 \nu}{2}\right) \frac{E_{\text {eff }}}{E}
$$

As is expected and as seen in equations (9) and (11), increasing the average fracture length or increasing the number of fractures in a given volume decreases the effective Young's modulus. Also, from equations (10) and (12) we see that the effective Poisson's ratio of a rock containing open, randomly oriented fractures is less than the intrinsic Poisson's ratio, while that for closed fractures is greater than the intrinsic ratio. It is important to recognize that relations (9) through (12) predict an isotropic stress-strain relation for fractured rock. 
If it is assumed that all the fractures are open and random, then equation (9) predicts that in the siltstones, shale, and coal the Young's modulus will be reduced about 80 percent from the laboratory values when there are 1,250 fractures of $10 \mathrm{~cm}$ average length per $\mathrm{m}^{3}$ and $\nu$ (the intrinsic Poisson's ratio) is between 0.30 and 0.39 . For the more massive sandstone and claystone, we find a 50-percent reduction in Young's modulus when there are 300 fractures of $10 \mathrm{~cm}$ average length per $\mathrm{m}^{3}$ and $\nu$ lies between 0.45 and 0.50 . The effective Poisson's ratios are seen to be reduced similarly (eq. 10).

If it is assumed that the fractures are closed and random, then equation (11) predicts that in the siltstones, shale, and coal the Young's modulus will be reduced by 62 percent from the laboratory values when there are 1,250 fractures of $10 \mathrm{~cm}$ average length per $\mathrm{m}^{3}$, and $\mu$, the coefficient of sliding friction, is assumed to be 0.6 (a typical value for rock). For the massive sandstone and claystone, we find a 28 -percent reduction in Young's modulus when there are 300 fractures of $10 \mathrm{~cm}$ average length per $\mathrm{m}^{3}$ and $\mu$ is 0.6 . The effective Poisson's ratios are seen by equation (10) to increase to 0.42 and 0.46 when $\mu$ lies between 0.30 and 0.39 (shale, coal, and siltstone intrinsic $\nu$ ) and will be 0.475 and 0.5 when $\nu$ lies between 0.45 and 0.50 (sandstone and claystone intrinsic $v$ ).

Besides the effects on Young's modulus and Poisson's ratio, the joints also affect the cohesion and the angle of internal friction. For example, Jaeger and Cook (1969, p. 391) thought that under the confining pressures the angle of internal friction for closely jointed rock is greater than that of the same rock without joints. Thus, under these conditions the Coulomb-Mohr envelope for the closely jointed rock will have a greater slope $(\tan \phi)$ than that of the intact rock and hence a lower cohesion. 
Since no theoretical basis exists for predicting the angle of internal friction or the cohesion of cracked rock, we have, in most of our stability calculations, made the conservative assumptions that $\phi$ is unchanged from the laboratory values and that the cohesion is zero.

Highwall stability predictions

In this analysis we considered the effects of slope geometry and material properties on highwall stability. The effects of pore-water pressure were not included.

Figure 15 shows an idealized open-pit cross section in the Fort Union Formation. Relative thicknesses of rock types in the cross section are determined from the schematic stratigraphic column in figure 16. Finiteelement meshes for the stability calculations were overlaid on figure 15. Only gravity loads were considered. Boundary conditions assumed for the calculations were fixed vertical displacements on the lower boundary and fixed horizontal displacements on the right- and left-hand boundaries of the finite-element meshes. These boundaries coincide with those shown in figure 15. Potential surfaces of failure for which safety factors were calculated are shown in figure 17. The dashed line in the figure indicates the geometry after removal of the coal bench. Safety factors for both geometries were determined.

We considered the effects of changing rock properties on the safety factors. Presumably, in a degrading highwall, the moduli (Young's moduli and Poisson's ratios) and strength parameters (cohesion and angle of internal friction) will all be affected by cracking; but, since we desired to understand the effects of each of these parameters, four different materialproperty cases were considered: The first case is that in which the values for the properties given in figure 15 were used. In the second case, the 
Figure 15.--Idealized cross section through an open-pit mine in the Fort Union Formation. The averages of laboratory-determined properties for the layers are shown in the table above.

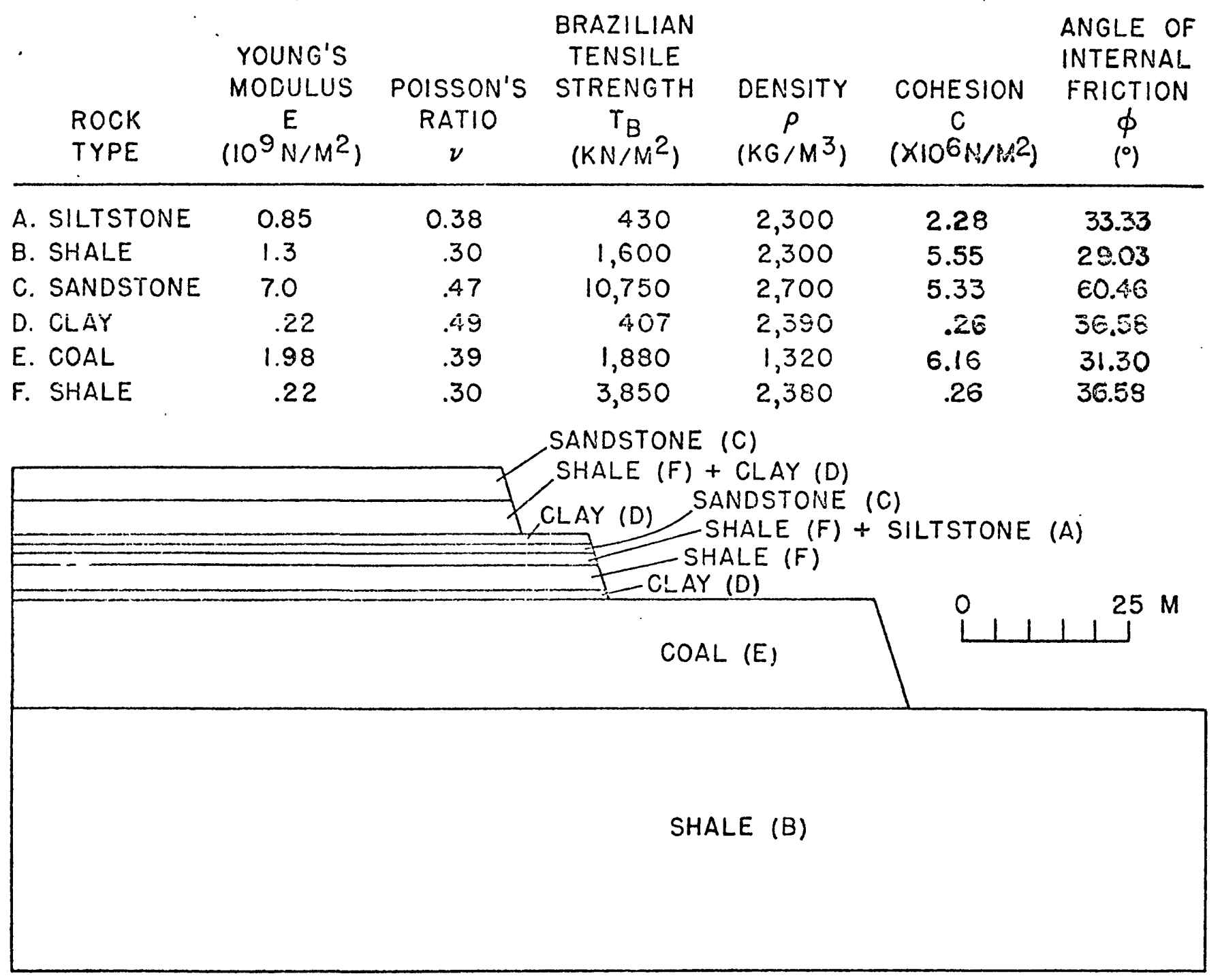




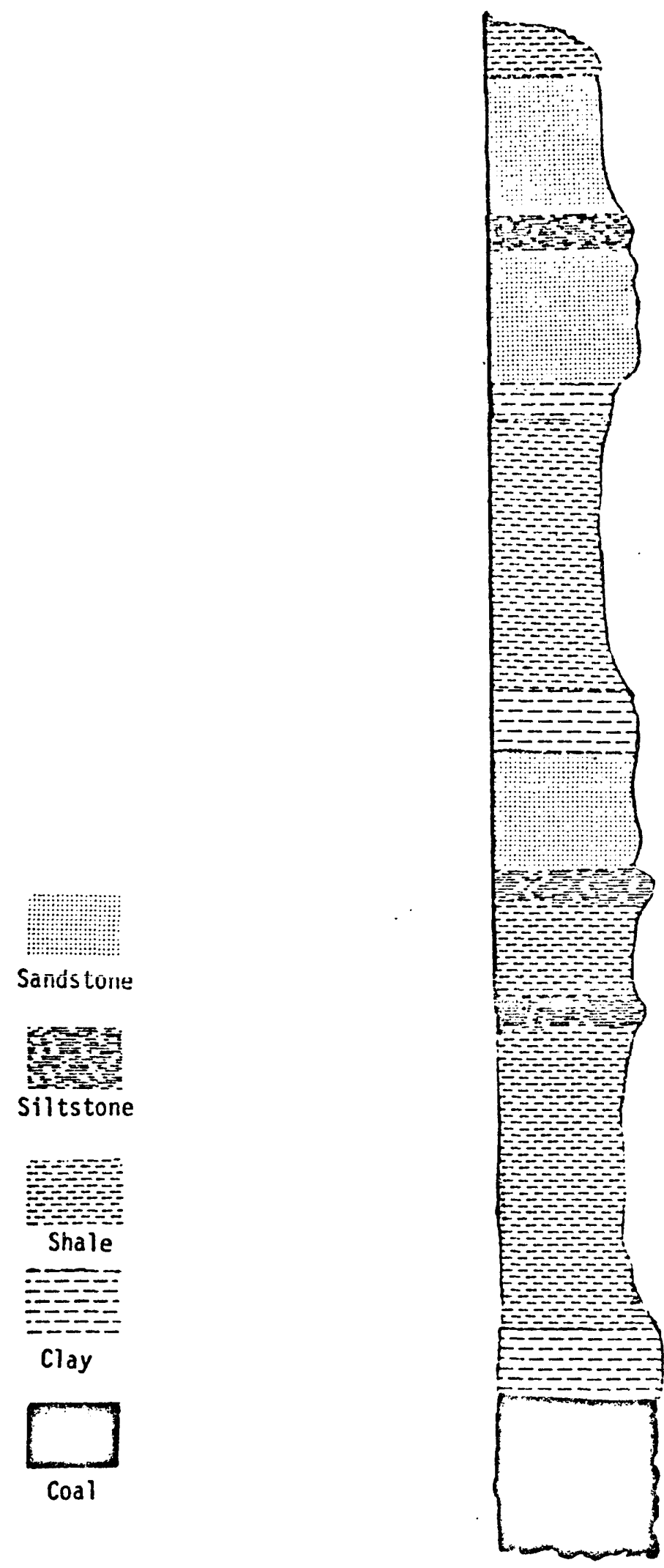

Figure 16.--Generalized stratigraphic column through the Decker mine showing relative amounts of the various overburden rock types. 
Figure 17.-.-Potential surfaces of failure for which safety factors were calculated. The dashed line indicates the geometry after removal of the coal bench.

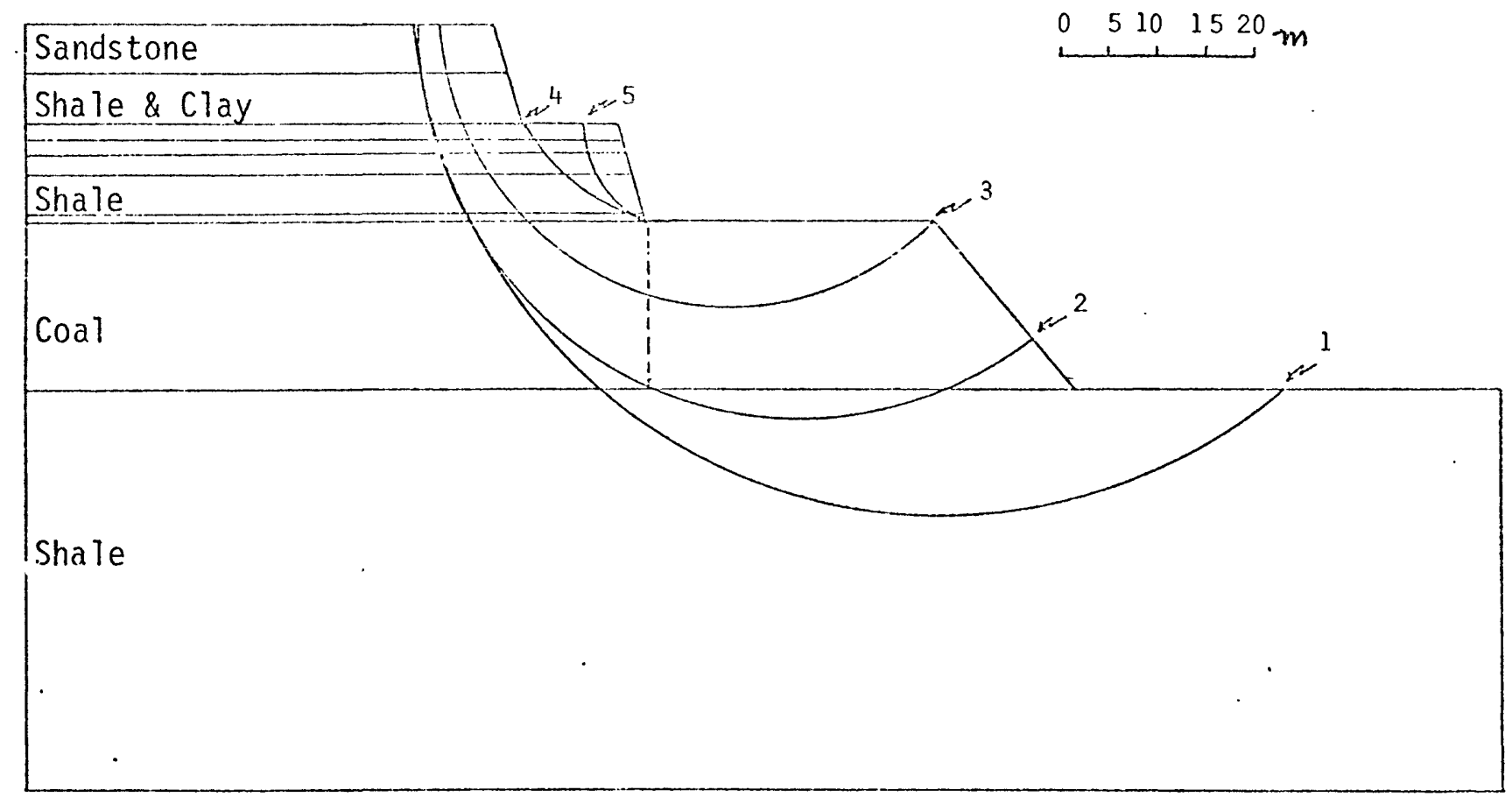


cohesion of each layer was reduced to zero; this reduction was made in an attempt to account roughly for the effect of fractures in the rock layers on the strength (as explained in the last section). In the third case we assumed that the rock in each layer was weakened by closed random fractures. The modifications in moduli are (as given in the preceding section) a 62percent reduction in Young's modulus for siltstone, shale, and coal; a 28-percent reduction in the sandstone and claystone; and an increase in Poisson's ratios to the range 0.42 to 0.50 . Here again, the cohesion is taken to be zero. In the fourth case, rock in each layer was assumed to be weakened by open, random cracks. The reductions in Young's modulus are (as given in the preceding section) 80 percent for the siltstones, shale, and coal and 50 percent for the sandstone and claystone, with the same reductions in Poisson's ratios. Cohesions are again set to zero.

Safety factors for the five potential failure surfaces are given in table 5. Note that when the average laboratory values are used (case 1), the safety factors are quite high for all surfaces--whether the coal bench is present or absent. On the other hand, when the cohesions are zero (case 2), safety factors are drastically reduced but still relatively high (the safety factor in this case is less than 2 only on surfaces 3 and 5 , fig. 17, after removal of the coal bench).

The introduction of closed cracks (case 3) in most instances increases the safety factors relative to those in case 2 (the exceptions are safety factors on surfaces 3 and 5, fig. 17, when the coal bench is absent). This increase is attributed to the high Poisson's ratios in the closed-crack model. This causes lateral stresses to increase relative to vertical stresses. Consequently, deviatoric stresses are smaller and failure is less pervasive in the highwall than in case 2 . 


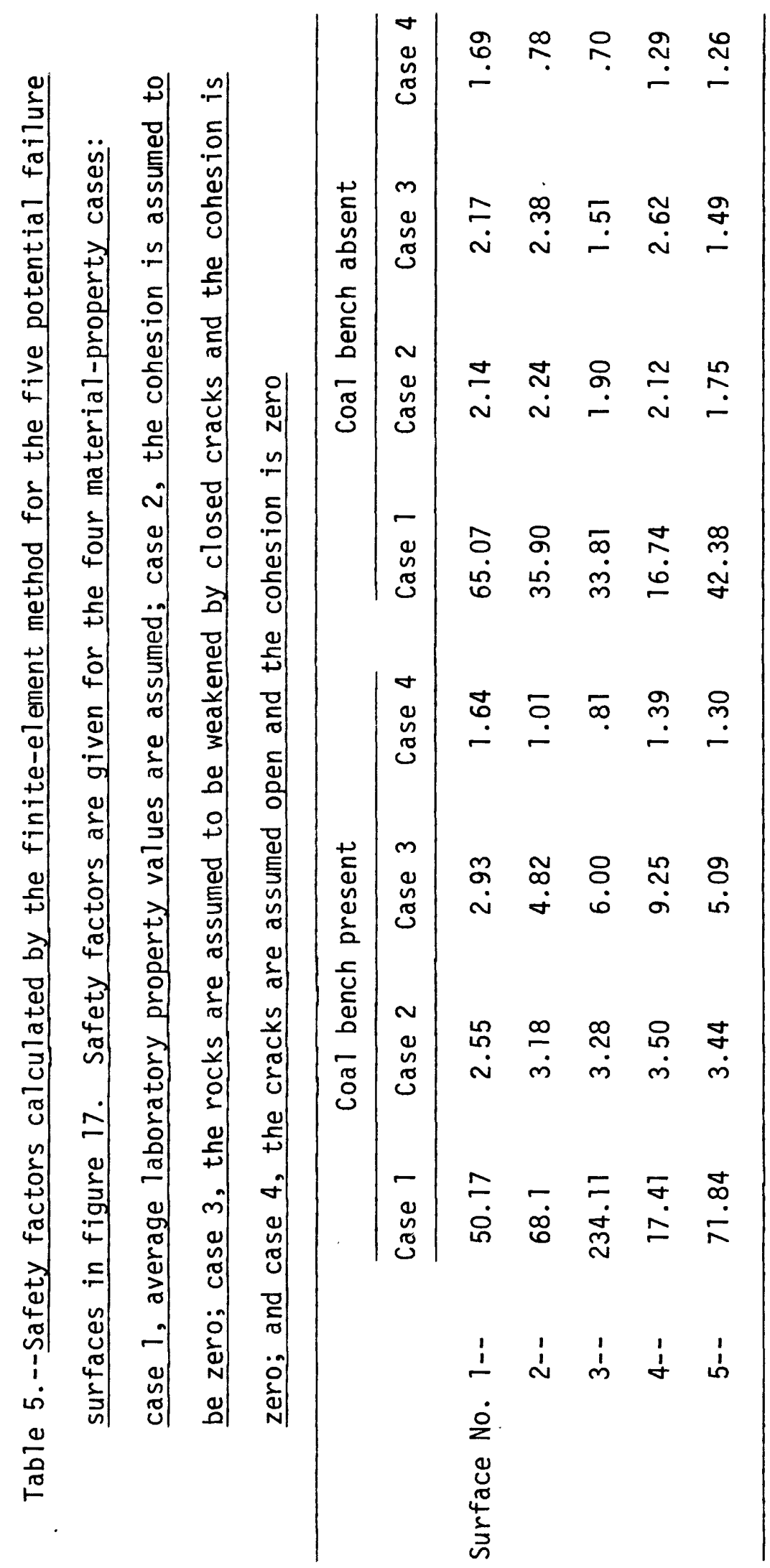


The lowest safety factors occur in the open-crack case. Because of the drastic modulus reductions, failure or near failure is predicted on surfaces 2 and 3 of figure 17 both before and after removal of the coal bench. Such large modulus reductions could occur if the slopes were allowed to deteriorate (as discussed earlier) during a delay in mining. With resumption of mining, failure along surfaces such as 2 and 3 (fig. 17) would be likely and would be hazardous to miners and mining equipment.

\section{CONCLUDING REMARKS AND FUTURE PLANS}

A search of recent technical literature and environmental impact statements revealed that very little effort is being made to design highwalls in the Powder River Basin in a quantitative manner on the basis of geologic and hydrologic conditions and physical properties of the overburden and coal. In a recent survey of surface coal mining procedures, Breslin and Anderson (1974) noted that very few mining companies utilized engineering design for their highwalls or monitored deformation. The same authors called attention to the marginal stability of many highwalls, and they noted that "members of the team were often cautioned not to approach the base of the highwall too closely." We also recognize, however, that the margin of safety of a highwall should depend upon the function of that slope. Because, as we have seen, slope deformations in the study area are time dependent, the margin of safety will vary with the purpose and anticipated lifetime of the slope. Open-pit mining practice in the study area is customarily based on an empirical approach, utilizing local site conditions and the observed behavior of nearby slopes. This is understandable, because the overburden depths are small at most mines in the study area and large-scale slope failures are infrequent at present. However, empirical procedures may be inadequate if conditions change or if new mines are opened without reference to past slope 
performance of nearby slopes. The margin of safety of these slopes is unknown, and in our field studies several failures and incipient failures were noted. At the Big Sky mine in Colstrip, Mont., part of the highwall which was about $52 \mathrm{~m}$ high failed at a slope angle of approximately $70^{\circ}$. This apparently occurred because of oversteepening of the wall at the lease-1ine boundary. It is our aim to develop a general understanding of the stability of such slopes so that hazardous highwall conditions can be better understood and avoided. Highwall conditions will become more unstable after the more shallow coals (less than $30 \mathrm{~m}$ of overburden) are mined and the mining of coals with deeper overburden becomes necessary, especially if presently used empirical designs become inadequate. The second part of the investigation will utilize field measurements of rockmass properties and instrumentation of actively mined pit slopes to obtain data for comparison with the results of the initial investigation.

Because we need to know how closely our analyses represent the behavior of typical slopes in response to mining, we plan to carry out an instrumentation and monitoring program at the Decker mine during the spring and summer of 1977. This program will involve measuring the elastic and time-dependent movements and stress changes as a bench of coal is removed from the toe of the highwall (figs. 18, 19).

Most of the deformation monitoring will be accomplished by precision analytical terrestrial photogrammetry. Four lines of targets, $25 \mathrm{~m}$ apart, will be attached to the highwall at the top, midheight, and bottom of each bench, as shown in figure 18. On the regraded spoil bank opposite the instrumented area, four fixed pedestals will be established for phototheodolite stations. Four Wild P-30 phototheodolites will be set up on the pedestals; then the orientation elements will be measured and the targeted 


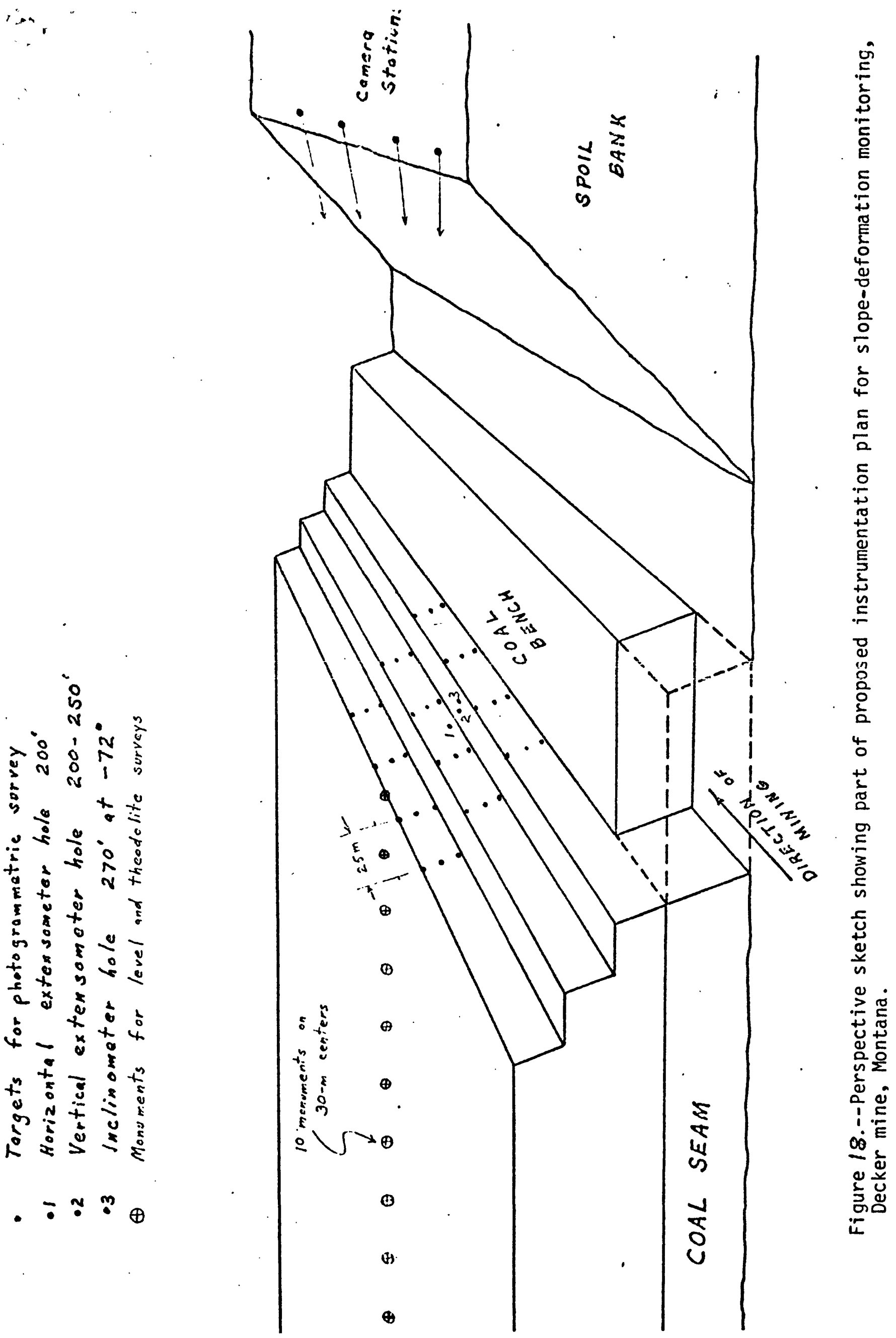




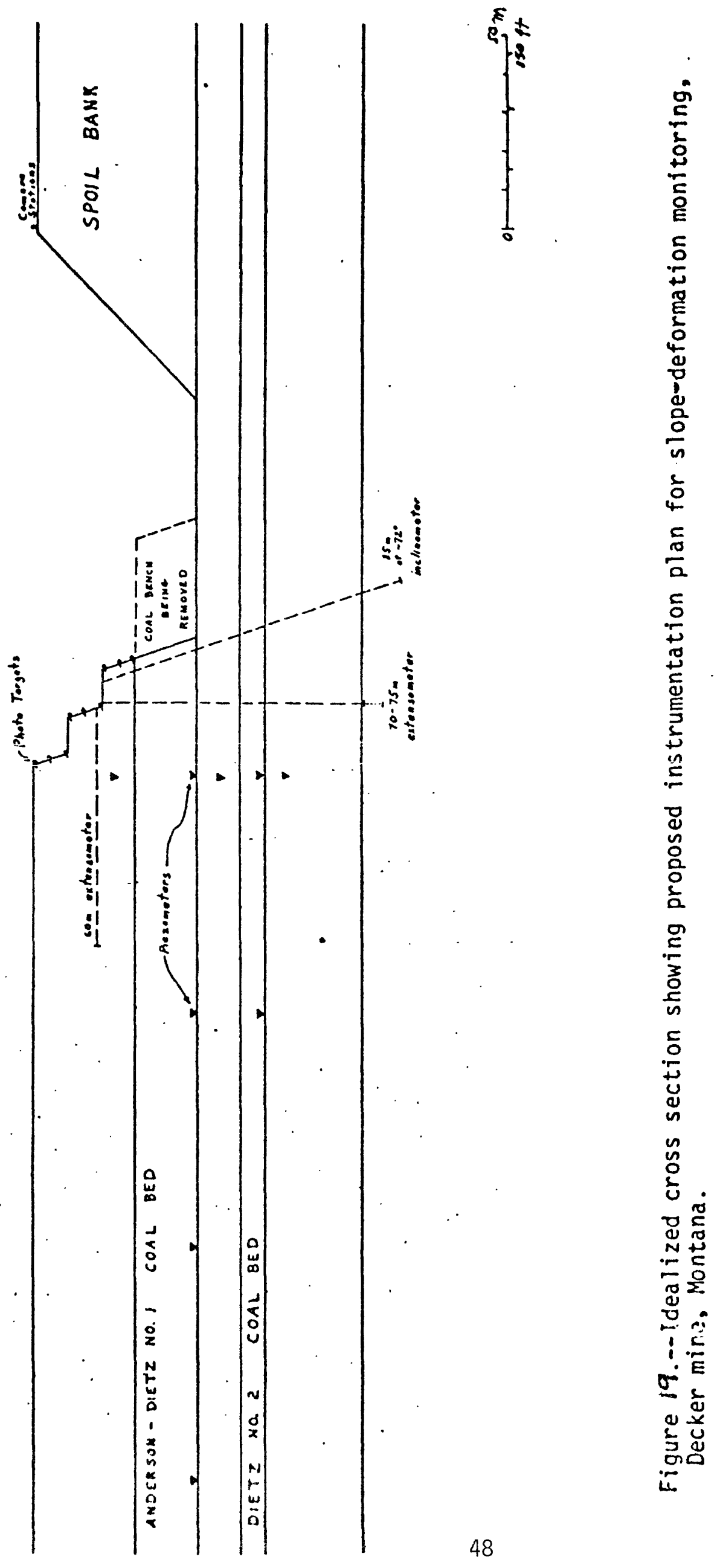


area photographed from each of the stations. The photographic coordinates of the targets will then be measured with a monocomparator and the space coordinates computed using a least-squares, space-intersection analysis. It is hoped that this procedure will give space coordinates of the targets within $5 \mathrm{~mm}$.

Other instruments to be installed include multiple-position borehole extensometers, as shown in figure 19. In addition, one borehole inclinometer hole that extends under the coal seam being mined should give detailed subsurface deformation data. One or two USGS 3-D borehole stress probes installed near the face will give data on changes in the stress field within the rock mass.

In order to quantitatively assess the effect of ground-water pressures on the behavior of the pit slopes, we plan to install about 10 piezometers. Five of these would be in the Anderson-Dietz No. 1 bed, in a line extending away from the face for about $300 \mathrm{~m}$. Two would be in the Dietz No. 2 bed, one below the Dietz No. 2, one between the two seams, and one above the Anderson-Dietz No. 1. Additional physical-property testing is planned, which will include in situ modulus tests and large-specimen $(30-\mathrm{cm})$ direct shear tests. Results from this monitoring program will be compared with behavior calculated from the finite-element analyses, and then a more accurate predictive model will be developed, which can be extended to greater overburden depths and to multiple-seam mining plans. 


\section{REFERENCES CITED}

Baligh, M. M., 1973, Numerical study of uniaxial and triaxial rock compression tests--Final report to Advanced Research Projects Agency, Contract H0220047: La Jolla, Calif., Systems, Sci., and Software, $159 \mathrm{p}$.

Bishop, A. W., 1955, The use of the slip circle in stability analysis of slopes: Geotechnique, v. 5, no. 1, p. 7-17.

Bjerrum, Laurits, 1967, Progressive failure in slopes of overconsolidated plastic clay and clay shales: Am. Soc. Civil Engineers Proc., v. 93, paper 5456, Jour. Soil Mechanics and Found. Div., no. SM5, pt. 1, p. $1-49$.

Breslin, J. J., and Anderson, R. J., 1974, Observations on the surface mining of coal: Columbus, Ohio, Battelle Memorial Inst. Energy Program Rept., 94 p.

Corp, E. L., Schuster, R. L., and McDonald, M. M., 1975, Elastic-plastic stability analys is of mine-waste embankments: U.S. Bur. Mines Rept. Inv. 8069,98 p.

Drucker, D. C., and Prager, W. J., 1952, Soil mechanics and plastic analysis or limit design: Appl. Mathematics Quart., v. 10, no. 2, p. 157-165.

Fahy, M. P., and Smith, W. K., 1976, Geotechnical properties of some upper Fort Union rocks from the Decker area, Big Horn County, Montana: U.S. Geo1. Survey Open-File Report 76-596, 112 p.

Fleming, R. W., Spencer, G. S., and Banks, D. C., 1970, Empirical study of clay shale slopes: U.S. Army Nuclear Cratering Group Tech. Rept. 15, v. 1,93 p.; v. 2, 304 p. 
Jaeger, J. C., and Cook, N. G. W., 1969, Fundamentals of rock mechanics: London, Methuen and Co. Ltd., 513 p.

Keefer, W. R., 1974, Regional topography, physiography, and geology of the northern Great Plains: U.S. Geol. Survey Open-File Report 74-50, 17 p., 4 pls.

Law, B. E., and Grazis, S. L., 1972, Preliminary geologic map and coal resources of the Decker quadrangle, Big Horn County, Montana: U.S. Geol. Survey open-file report, 3 sheets.

Matson, R. E., and Blumer, J. W., 1973, Quality and reserves of strippable coal, selected deposits, southeastern Montana: Montana Bur. Mines and Geology Bu11. 91, 135 p. [1974].

McKenna, M. C., and Love, J. D., 1972, High-level strata containing early Miocene mammals on the Bighorn Mountains, Wyoming: Am. Mus. Novitates, no. 2490,30 p.

Morgenstern, N. R., and Price, V. E., 1965, The analysis of the stability of general slip surfaces: Geotechnique, v. 15, no. 1, p. 79-93.

Smith, C. K., and Redlinger, J. F., 1953, Soil properties of Fort Union clay shale [N. Dak.]: Internat. Conf. Soil Mechanics and Found. Eng., 3d, Switzerland, Proc., sess. 1/15, v. 1, p. 62-66.

Taff, J. A., 1909, The Sheridan coal field, Wyoming, in Coal fields of Wyoming: U.S. Geo1. Survey Bu11. 341-B, p. 123-150.

Underwood, L. B., 1967, Classification and identification of shales: Am. Soc. Civil Engineers Proc., v. 93, paper 5560, Jour. Soil Mechanics and Found. Div., no. SM6, p. 97-116. 
Underwood, L. B., Thorfinnson, S. T., and Black, W. T., 1964, Rebound in redesign of Oahe Dam hydraulic structures: Am. Soc. Civil Engineers Proc., v. 90, paper 3820, Jour. Soil Mechanics and Found. Div., no. SM2, pt. 1, p. 65-86.

Van Voast, W. A., 1974, Hydrologic effects of strip mining in southeastern Montana--emphasis; one year of mining near Decker: Montana Bur. Mines and Geology Bu11. 93, $24 \mathrm{p}$.

Walsh, J. B., 1965a, The effect of cracks on the compressibility of rock: Jour. Geophys. Research, v. 70, no. 2, p. 381-389. 1965b, The effect of cracks on the uniaxial elastic compression of rocks: Jour. Geophys. Research, v. 70, no. 2, p. 399-411. 1965c, The effects of cracks in rocks on Poisson's ratio: Jour. Geophys. Research, v. 70, no. 20, p. 5249-5257.

Wang, F. D., and Sun, M. C., 1970, Slope stability analysis by the finite element stress analysis and limiting equilibrium method: U.S. Bur. Mines Rept. Inv. $7341,16 \mathrm{p}$. 
